\title{
An Experimental Study of the Response of the Galesville Sandstone to Simulated CAES Conditions
}

\author{
R. L. Erikson \\ J. A. Stottlemyre \\ R. P. Smith
}

July 1980

Prepared for the U.S. Department of Energy under Contract DE-AC06-76RLO 1830

Pacific Northwest Laboratory

Operated for the U.S. Department of Energy by Battelle Memorial Institute 


\title{
NOTICE
}

This report was prepared as an account of work sponsored by the United States Government. Neither the United States nor the Department of Energy, nor any of their employees, nor any of their contractors, subcontractors, or their employees, makes any warranty, express or implied, or assumes any legal liability or responsibility for the accuracy, completeness or usefulness of any information, apparatus, product or process disclosed, or represents that its use would not infringe privately owned rights.

The views, opinions and conclusions contained in this report are those of the contractor and do not necessarily represent those of the United States Government or the United States Department of Energy.

\author{
PACIFIC NORTHWEST LABORATORY \\ operated by \\ BATTELLE \\ for the \\ UNITED STATES DEPARTMENT OF ENERGY \\ Under Contract DE-AC06-76RLO 1830
}

\author{
Printed in the United States of America \\ Available from \\ National Technical Information Service \\ United States Department of Commerce \\ 5285 Port Royal Road \\ Springfield. Virginia 22151
}

Price: Printed Copy $\mathbf{S}$

$\because$ Microfiche $\$ 3.00$

NTIS

•Pages Selling Price

$\begin{array}{ll}001-025 & \$ 4.00 \\ 026-050 & \$ 4.50 \\ 051-075 & \$ 5.25 \\ 076-100 & \$ 6.00 \\ 101-125 & \$ 6.50 \\ 126-150 & \$ 7.25 \\ 151-175 & \$ 8.00 \\ 176-200 & \$ 9.00 \\ 201-225 & \$ 9.25 \\ 226-250 & \$ 9.50 \\ 251-275 & \$ 10.75 \\ 276-300 & \$ 11.00\end{array}$




\section{4}

\section{AN EXPERIMENTAL STUDY OF THE RESPONSE \\ OF THE GALESVILLE SANDSTONE TO SIMULATED CAES CONDITIONS}

R. L. Erikson

J. A. Stottlemyre

R. P. Smith

July 1980

Prepared for

the U.S. Department of Energy

under Contract DE-AC06-76RLO 1830

Pacific Northwest Laboratory

Richland, Washington 99352 



\section{PREFACE}

Compressed air energy storage (CAES) is a technique for storing heated air in an underground reservoir; the air can subsequently be withdrawn, mixed with fuel, burned, and allowed to expand through turbines to generate peak power in electric utility systems. Several types of geologic reservoirs, including mined salt cavities, hardrock caverns, and aquifers, have been proposed for CAES. The technical and economic feasibility of CAES technology depends to a major extent on locating, developing, and maintaining an adequate subsurface reservoir. A fundamental uncertainty is the manner in which a reservoir might physically and chemically respond to new environmental conditions imposed by CAES operation.

The laboratory investigation discussed in this report addresses the possible interactions of air and water with an aquifer sandstone under environmental conditions anticipated for CAES. It is part of a Reservoir Stability Program designed to develop criteria for the long-term operation of underground reservoirs used for compressed air energy storage. The Compressed Air Energy Storage Technology Program at the Pacific Northwest Laboratory (PNL) is sponsored by the Department of Energy, Division of Energy Storage Systems. PNL is operated for the Department of Energy by Battelle Memorial Institute. 


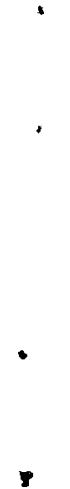


The objective of this experimental study was to determine how the mineralogical and physical characteristics of host rock formations are affected by environmental conditions anticipated for compressed air energy storage (CAES) in porous, permeable rock. In this study, Galesville sandstone cores were reacted in autoclave pressure vessels supporting one of four environments: 1) dry air, 2) heated, air-water vapor, 3) heated, nitrogen-water vapor mixtures, and 4) heated, compressed, liquid water. The simulated CAES environments were maintained in autoclave pressure vessels by controlling the following independent variables: 1) temperature, 2) pressure, 3) time, 4) oxygen content, 5) carbon dioxide content, 6) nitrogen content, and 7) liquid volume. The dependent variables studied were: 1) apparent porosity, 2) gas permeability, 3) water permeability, and 4) friability. These variables were measured at ambient temperature and pressure before and after each sandstone sample was reacted in one of the CAES environments.

The dry air and gas-water vapor tests were designed to simulate CAES conditions. The liquid tests were designed to monitor groundwater chemical changes resulting from reaction of sandstone in an aqueous fluid. The liquid tests may also simulate isolated, low permeability zones which may remain saturated (irreducible water content) under actual CAES field conditions.

The experiments gave the following results:

- The Galesville sandstone exhibited excellent stability in dry air at a 11 temperatures tested $\left(50^{\circ}\right.$ to $\left.300^{\circ} \mathrm{C}\right)$.

- Significant physical alterations occurred in sandstone samples exposed to liquid water above $150^{\circ} \mathrm{C}$.

- Preliminary experiments had indicated that significant physical alterations occurred in sandstone samples exposed to gas-water vapor mixtures above $150^{\circ} \mathrm{C}$. However, these alterations were later proven to be the result of water condensation inside the pressure vessel. In later experiments, samples shielded from dripping water exhibited excellent stability to $300^{\circ} \mathrm{C}$. 
- The porosity and friability of the sandstone samples increased as a function of increased temperature, humidity, and/or testing time.

- The sandstone also exhibited greater changes in gas and liquid permeability with increased temperature, humidity, and/or testing time. However, both permeability increases and decreases were observed.

- The changes in the physical stability of the sandstone were postulated to result from the dissolution of interstitial quartz cement binding the individual grains.

- Sandstone may be a suitable storage media for heated, humid air provided elevated temperature zones are relatively free of mobile liquid water.

- Observed changes in the physical properties of the rock may have been caused, in part, by the lack of confining stress on the sample. The inability to apply confining pressure is a severe limitation of autoclave experiments.

Future experiments will be conducted in the CAES triaxial/fluid flow test facility being completed at PNL. This facility will eliminate many of the limitations of autoclave pressure vessels and will allow a more accurate determination of physical and chemical property changes in porous media exposed to simulated CAES conditions. 


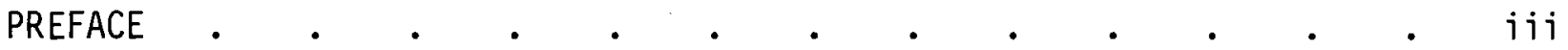

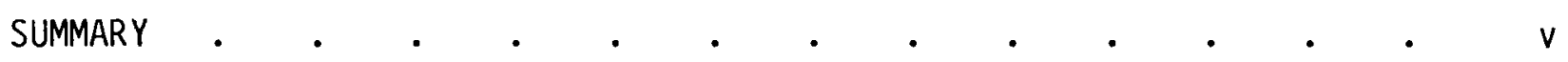

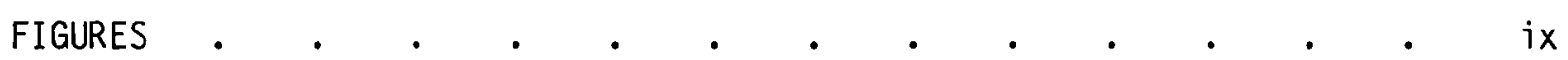

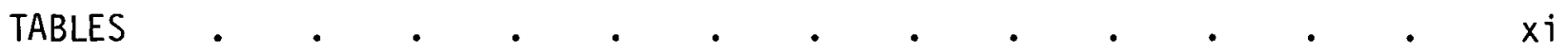

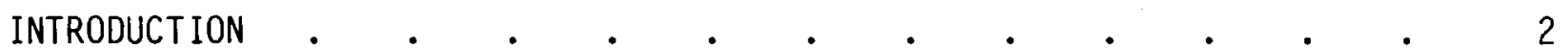

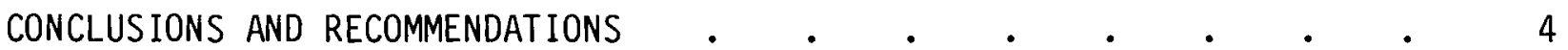

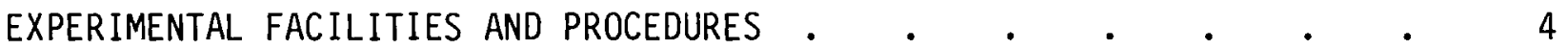

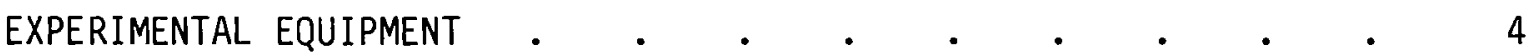

SAMPLE PREPARATION AND CHARACTERIZATION • . . . . . . . . 6

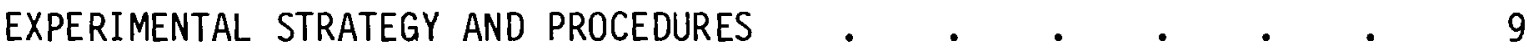

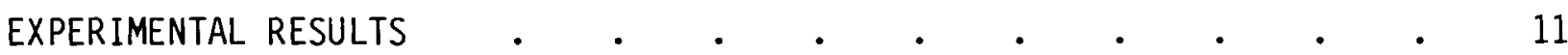

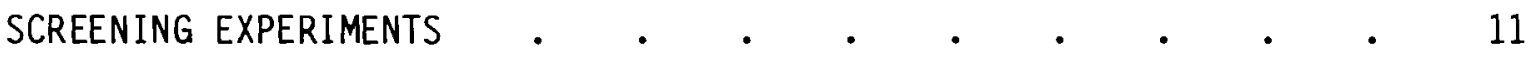

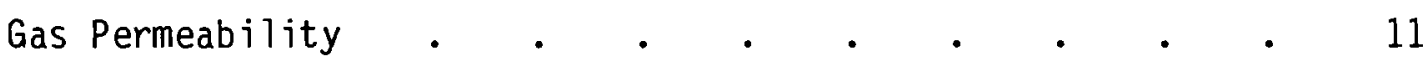

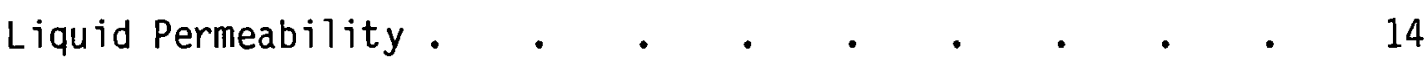

Matrix Friability . $\quad$. $\quad$. $\quad$. . . . . . 14

DETAILED EXPERIMENTS $\quad$ • $\quad$ • $\quad$ •

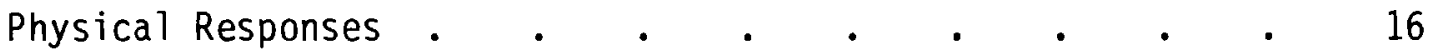

Chemical Responses .

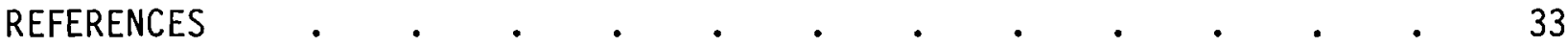

APPENDIX A - EXPERIMENTAL DATA FOR GALESVILLE SANDSTONE $\quad$ • • • • A.1

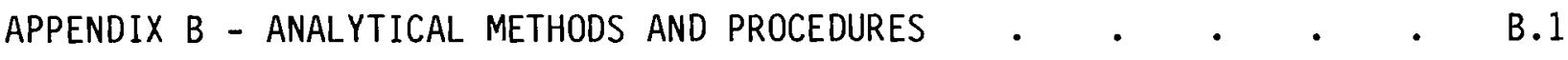




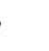




\section{FIGURES}

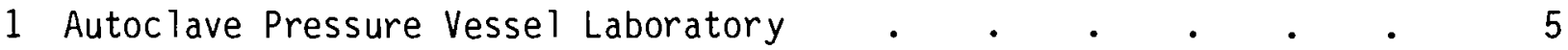

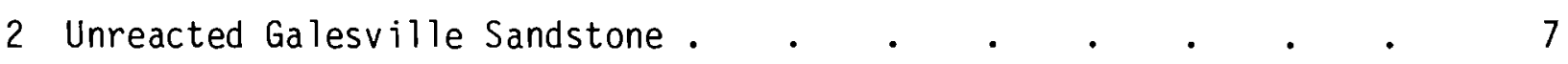

3 Percent Change in Gas Permeability . . . . . . . . . 13

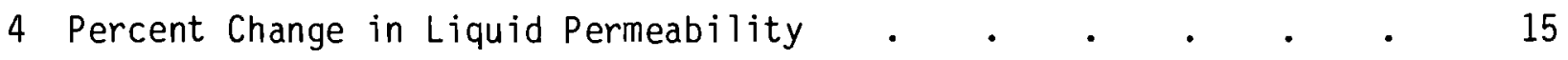

5 Percent Change in Matrix Friability . . . . . . . . . 15

6 Increasing Disaggregation of Galesville Samples Reacted in a High Humidity Environment at Elevated Temperatures . • . . . . 17

7 Results of a) Experiment G-26 (Cores J-19 and J-13) and

b) Experiment G-5 (Core D-5) . . . . . . . . . . 19

8 Percent Change in Gas Permeability with Temperature . . . 20

9 Percent Change in Water Permeability with Temperature . . . 21

10 Percent Change in Friability with Temperature . . . . . . . 22

11 Percent Change in Apparent Porosity with Temperature . . . . 23

12 Elemental Fluid Concentrations (mg/l) Versus Time for EXP G-11 • 26

13 Elemental Fluid Concentrations (mg/l) Versus Time for EXP G-1 . 27

14 Galesville Sandstone After Heating to $300^{\circ} \mathrm{C}$

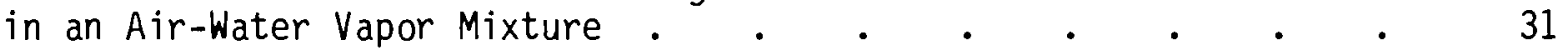

B.1 Pre-Test Apparent Porosity of the Galesville Sandstone . • • B.2

B.2 Pre-Test Gas and Liquid Permeabilities of the Galesville Sandstone B.3

B.3 Sampling Apparatus for Extracting Liquid and Gas Samples • • B.6 


\section{TABLES}

1 Approximate Mineralogy of the Galesville Sandstone . $\quad$. $\quad$. $\quad 6$

2 Chemical Composition of Synthetic Groundwater . $\quad$. $\quad$ • $\quad$ • 9

3 Range of Independent Variables . . . . . . . . . . 10

4 Test Matrix for Screening Experiments . . . . . . . 12

5 Chemical Composition of Groundwater . . . . . . . . . . 25

6 Comparative X-ray Diffraction Data for Unreacted Galesville

7 Comparative $X$-Ray Fluorescence Data for Sandstone

Cores D-4 and D-5 . . 30 


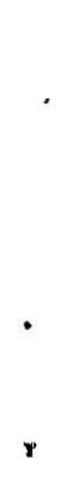

. 


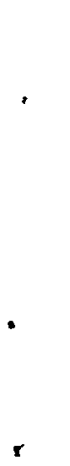

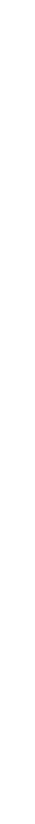

, 


\section{AN EXPERIMENTAL STUDY OF THE RESPONSE \\ OF THE GALESVILLE SANDSTONE TO \\ SIMULATED CAES CONDITIONS}

\section{INTRODUCTION}

The Galesville sandstone (located at the Media natural gas storage field, Illinois) appears to be a reasonable candidate rock for compressed air energy storage (CAES). This sandstone is currently under consideration for a CAES field demonstration. However, it is not known how this sandstone will physically and chemically behave in the hot, humid conditions anticipated for CAES. This laboratory study addresses the possible interactions of hot air and water with the Galesville sandstone.

Although the chemical composition is regionally variable, the samples used in this study are from a clean sandstone (approximately $100 \%$ quartz) that exhibits gas permeabilities, parallel to the bedding planes, ranging from 20 to 2400 millidarcies ( $\mathrm{md}$ ). To determine how the reservoir rock may respond to anticipated CAES conditions, cylindrical cores of sandstone were reacted in autoclave pressure vessels. The physical rock properties of primary interest include apparent porosity, gas permeability, liquid permeability and friability. These physical properties for individual sandstone cores were measured before and after each core had been subjected to various combinations of pressure, temperature, humidity, gas composition, and experiment duration.

This report gives the results of the experiments, along with the procedures used. Appendix A lists the experimental data, and Appendix B details the analytical methods and procedures. The reported results are applicable only to the specific samples of Galesville sandstone used in these experiments. Experimental results and conclusions should be viewed in a qualitative sense; the diversity of physical and chemical properties for porous rocks generally does not warrant an extrapolation of quantitative results between different rock types. As CAES candidate sites are selected, each potential host rock should be evaluated with the tools and methodology developed in the Reservoir Stability Program. 
CONCLUSIONS AND RECOMMENDATIONS

The following observations and conclusions may be deduced from the experimental results:

- The Galesville sandstone appears to be physically stable at temperatures between $50^{\circ}$ and $300^{\circ} \mathrm{C}$ if exposed to dry air.

- Physical alterations of the sandstone exposed to liquid or vapor phase water at temperatures less than $150^{\circ} \mathrm{C}$ were minimal for the duration of these experiments. Above $150^{\circ} \mathrm{C}$, the physical stability of the rock can be extensive, especially in a heated, liquid water environment.

- The porosity and friability of all sandstone samples increased as a function of increased temperature, humidity, or time.

- Gas and liquid permeability changes were also greater for those samples exposed to the higher temperature and humidity conditions. However, both increases and decreases in permeabilities were observed.

- Much of the scatter evident in the permeability results at high temperature was caused, in part, by the surface disaggregation of the sandstone cores. This disaggregation, especially for those cores reacted in heated groundwater, of ten prevented accurate determination of permeability. Applying a confining pressure to the sample to simulate the lithostatic pressure (weight of overburden) in a CAES reservoir may alleviate this problem.

- The chemical composition of the groundwater monitored during experiments in which sandstone was reacted in liquid indicated insignificant changes in the concentrations of $\mathrm{Na}, \mathrm{K}, \mathrm{Mg}$, and $\mathrm{Ca}$ with time. The concentration of $\mathrm{Si}$ increased rapidly at first and then became constant with time. The change in the concentration of Si was most likely caused by dissolution of quartz. However, this chemical reaction was not detected in petrographic analys is of thin sections of reacted sandstone. 
- The dissolution of quartz cement was the probable cause for the disaggregation of the sandstone. This disaggregation could result in increased rock permeability. However, it is possible that dislodged particles may ultimately reduce the permeability by plugging the formation. An increase in permeability may be beneficial, but the potential for subsequent particulate plugging cannot be dismissed.

- Sandstone may be a suitable storage media for heated, humid air provided elevated temperature zones are relatively free of mobile, liquid phase water.

The results and conclusions presented in this report are considered preliminary due to the many limitations of autoclave pressure vessels previously described. The observed changes in permeability, porosity, and friability of sandstone may be attributed partly to the inability to accurately simulate CAES reservoir environments. In the porous media flow facility currently being fabricated, the following conditions can be simultaneously monitored: 1) triaxial load on the sample, 2) flow of heated, dry or humid air through porous geologic materials, (e.g., sandstone), 3) axial and radial deformation of the rock, 4) the pressure drop along the axis of the core, and 5) effluent air humidity. Using this apparatus, it will be possible to determine changes in the physical properties of the sandstone at the temperature and pressure of the experiment. Samples of reservoir rock subjected to the above conditions will provide more useful data on the physical and chemical stability of sandstone subjected to environments characteristic of CAES. 


\section{EXPERIMENTAL FACILITIES AND PROCEDURES}

The main objectives of the experiments were to identify: 1) independent variables that have significant impact on the experimental response of the rock, 2) independent variables that have a relatively small influence and can be held constant in future experiments, and 3) trends in the data that pertain to CAES reservoir design and/or operating criteria. The dependent variables of primary interest were: 1) gas permeability, 2) water permeability, 3) apparent porosity, and 4 ) rock friability.

\section{EXPERIMENTAL EQUIPMENT}

To adequately simulate field conditions anticipated for CAES, the sample should be heated, subjected to axial and radial confining pressure, and ventilated with air of known pressure, humidity, temperature, and flow rate. Measurements of the pressure drop along the axis of the rock core, axial and radial deformation, effluent air humidity and suspended particle load are of principal concern. A facility that will meet these criteria is currently nearing completion at PNL. In the interim, autoclaves are being used to obtain preliminary data for humid air conditions. Cyclical dry air tests are being performed at the University of Wisconsin at Milwaukee.

Figure 1 illustrates the existing autoclave facility. Cylindrical sandstone specimens are subjected to one of four environments; 1) heated, dry air, 2) heated, humidified air, 3) heated, humidified nitrogen, or 4) heated liquid. The following independent variables can be controlled in the facility: 1) temperature $\left(25^{\circ}-300^{\circ} \mathrm{C}\right)$, 2) pressure $(1-175$ bars $\left.), 3\right)$ time (unrestricted), 4) oxygen content $(0-21 \%), 5)$ carbon dioxide content (0-1\%), 6) nitrogen content $(78-100 \%), 7)$ liquid volume $(0-600 \mathrm{ml})$, and 8) fluid stirring frequency $(0-250 \mathrm{rpm})$. Although autoclaves are an expedient means for obtaining preliminary data, certain limitations must be noted. The fundamental limitations of the autoclave experiments are: 1) no effective stress is imposed on the sample; 2) samples are subjected to an uncharacteristically large fluid/rock volume ratio; 3 ) no control of fluid transport is possible; and 4) permeability, porosity, and strength measurements are possible only at ambient temperature and pressure prior and subsequent to sample treatment. 


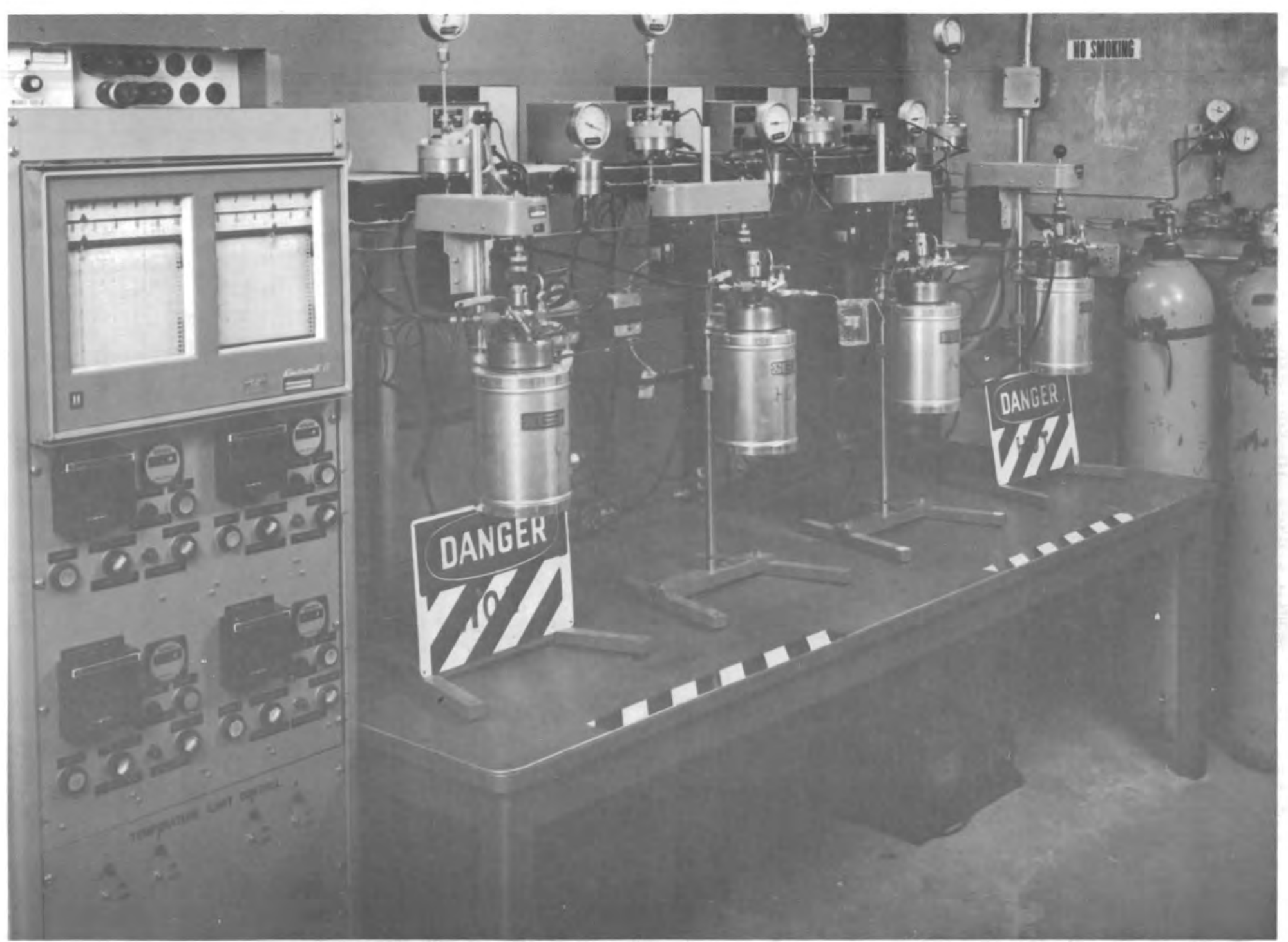

FIGURE 1. Autoclave Pressure Vessel Laboratory 
The Galesville sandstone samples used in the experiments were supplied by Geo-Engineering Laboratories, Inc. and the Northern Illino is Gas Company. Cores with 10-cm diameters were obtained from the Media natural gas storage reservoir. The Galesville sandstone is white to grayish-white and has an estimated mean grain size of $0.5 \mathrm{~mm}$. Petrographic examination revealed that the subangular clasts have equant to subequant forms. The rock is moderately well sorted and exhibits cyclic parallel bedding of thin, coarser-grained layers and thick, finer-grained layers.

Cylindrical cores $(1.8 \mathrm{~cm}$ diameter $\times 3.0 \mathrm{~cm}$ in length) were drilled, parallel to the bedding planes, from four field cores obtained from a depth of $685 \mathrm{~m}$. Each $1.8 \mathrm{~cm} \times 3.0 \mathrm{~cm}$ core was labeled with a letter prefix (i.e., D, $I$, J, or K), identifying the parent core from which it was cut, and a consecutive number.

The mineralogy was estimated from microscopic and X-ray diffraction techniques. The results showed the Galesville sandstone to be an orthoquartzite with the approximate mineralogy listed in Table 1 . The clasts are almost entirely quartz with trace amounts to $1 \%$ of feldspar that has been partially weathered to kaolinite. The cementing material is predominantly crystalline quartz and trace amounts of interstitial calcite. In addition to these minerals, the K-series parent core also contains small amounts of dolomite identified by $X$-ray diffraction analysis. Quartz was the only detectable phase present in $X$-ray diffractograms of the $D, I$, or $J$ series core material. Photomicrographs of thin-sectioned Galesville (D-series) sandstone are illustrated in Figures $2 a$ and $b$.

TABLE 1. Estimated Mineralogy of the Galesville Sandstone

\begin{tabular}{lccllc}
\multicolumn{1}{c}{ Mineral } & Volume $\%$ & & Mineral & Volume $\%$ \\
\cline { 5 - 5 } Quartz & 98 & & Dolomite & & $0-5$ \\
Feldspar & 1 & & Mica & & $<1$ \\
Kaolinite & $<1$ & & Opaques & $<1$ \\
Calcite & $<1$ & & &
\end{tabular}




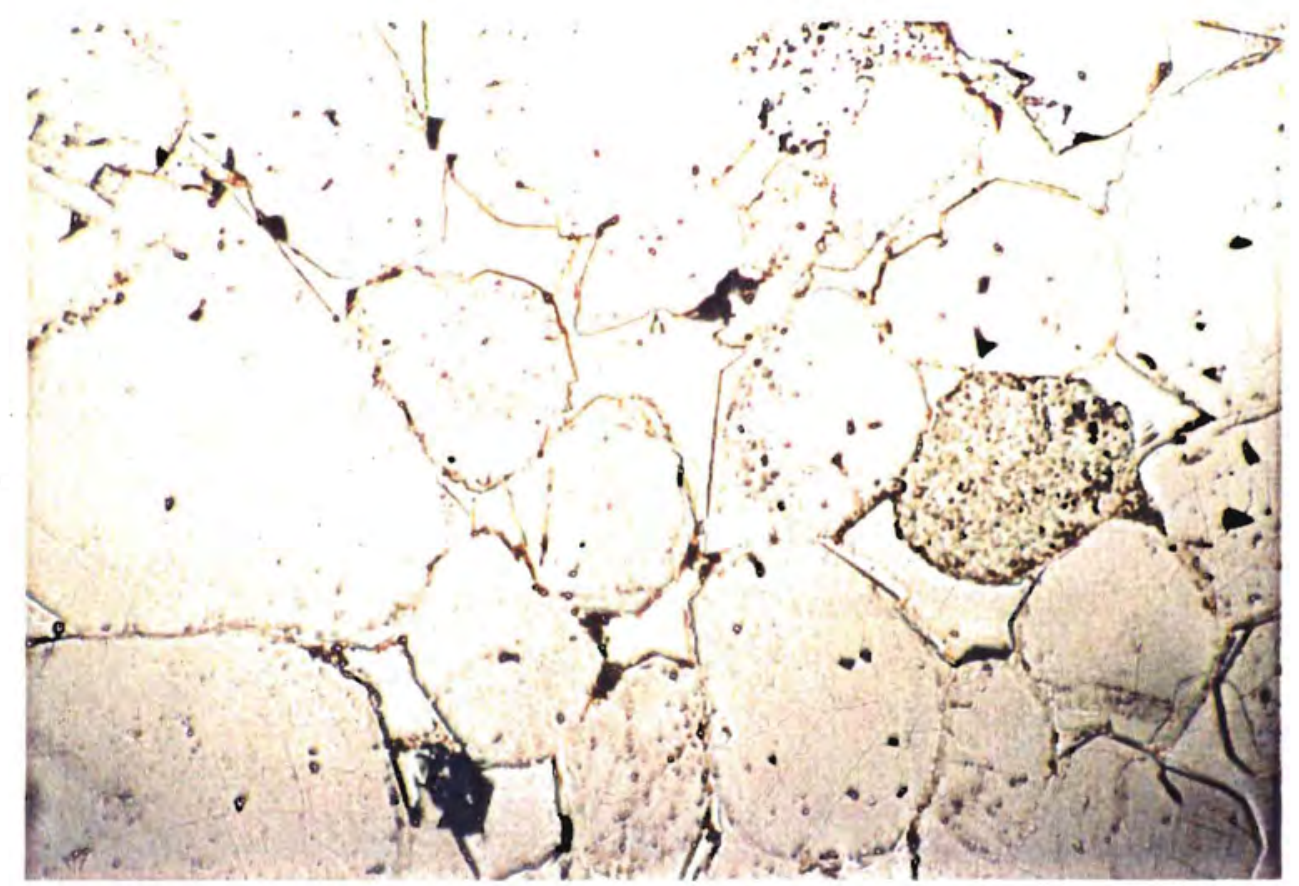

a. Plane Polarized Light (50X)

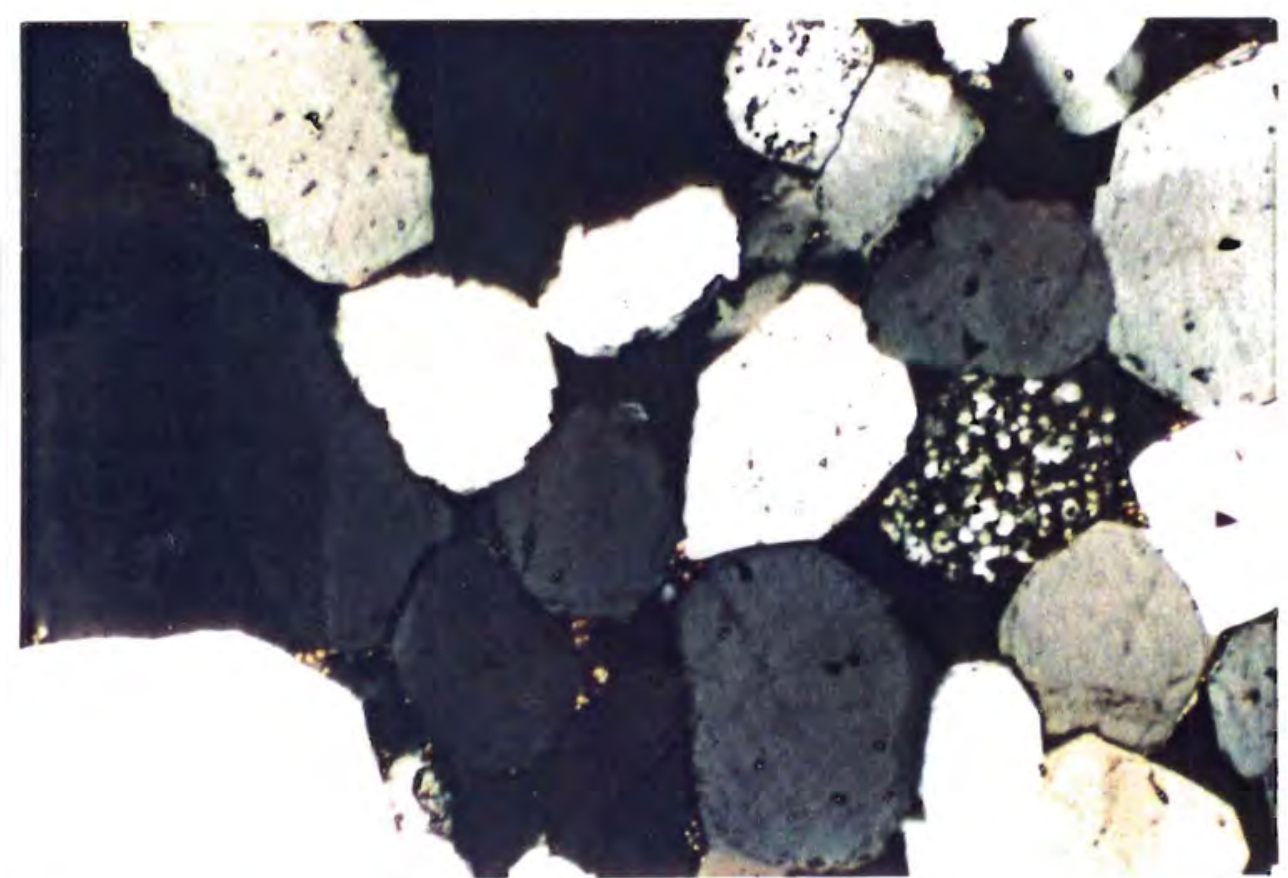

b. Crossed Nicols (Mottled Kaolinite, Yellow Calcite, Other Quartz) (50X)

FIGURE 2. Unreacted Galesville Sandstone 


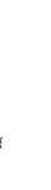

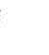


Groundwater from the Galesville sandstone horizon was collected and its chemical composition determined. A synthetic aqueous solution was prepared to simulate the chemical composition of actual waters currently in equilibrium with the Galesville. The composition of the synthetic groundwater used in these experiments is 1 isted in Table 2.

\begin{tabular}{|c|c|}
\hline Constitutents & Concentration $(\mathrm{mg} / \mathrm{l})$ \\
\hline $\mathrm{Na}$ & 430 \\
\hline $\mathrm{Ca}$ & 50 \\
\hline K & 200 \\
\hline $\mathrm{Mg}$ & 14 \\
\hline Si & $<0.05$ \\
\hline $\mathrm{SO}_{4}{ }^{2-}$ & 300 \\
\hline $\begin{array}{l}\mathrm{CO}_{3}{ }^{2-} \\
\text { Solution } \mathrm{pH}=\end{array}$ & 150 \\
\hline
\end{tabular}

\section{EXPERIMENTAL STRATEGY AND PROCEDURES}

The experimental work was completed in two parts: 1) screening experiments, and 2) detailed experiments. In the screening experiments, a PlackettBurman (1946) experimental design was selected to systematically investigate the response of the dependent variables to various combinations of maximum and minimum values of the independent variables. Using this method, insignificant independent variables could be eliminated from further consideration. The responses of the dependent variables were then determined as a function of intermediate values of the most significant independent variables in a set of detailed experiments. The total number of required experiments was significantly reduced by this experimental approach. The ranges of independent variables used in this study are listed in Table 3.

In all experiments, the sandstone samples were exposed to one of the following environments: 1) heated, dry air, 2) heated, air-water vapor or 
nitrogen-water vapor mixtures, or 3 ) heated, liquid (ground) water. Measurements of gas permeability, water permeability, and friability were obtained before and after each core had been reacted in one of the above environments. Apparent porosity was later added as a fourth dependent variable. Details of the measurement techniques for the dependent variables are discussed in Appendix B.

TABLE 3. Range of Independent Variables

\begin{tabular}{|c|c|c|}
\hline Variable & Minimum Value & Maximum Value \\
\hline Pressure (bars) & 60 & 120 \\
\hline Temperature $\left({ }^{\circ} \mathrm{C}\right)$ & 50 & 300 \\
\hline Time (months) & 0.5 & 2.0 \\
\hline 0xygen Content (\%) & 0.0 & 21.0 \\
\hline Carbon Dioxide Content ( $\%$ ) & 0.0 & 0.1 \\
\hline Nitrogen Content $(\%)$ & 78.0 & 100.0 \\
\hline Stirring Frequency (per day) & 0 & 8 \\
\hline Liquid Saturated Environment & No & Yes \\
\hline $\begin{array}{l}\text { Air and Vapor Saturated } \\
\text { Environment }\end{array}$ & No & Yes \\
\hline
\end{tabular}




\section{EXPER IMENTAL RESULTS}

The experimental results for the screening and detailed experiments are discussed in the following section. Results of gas permeability, water permeability, apparent porosity, and friability measurements as well as other physical and chemical responses of the sandstone are summarized.

\section{SCREENING EXPERIMENTS}

During the parametric screening survey of the Galesville sandstone, gas permeability, water permeability, and matrix friability were analyzed. Table 4 sumarizes the changes in relative percentage observed in values for the three dependent variables for each of 12 screening experiments. The experiments represent various maximum-minimum combinations of the independent variables (pressure, temperature, time, oxygen content, nitrogen content, carbon dioxide content, and humidity.)

\section{Gas Permeability}

The analysis of the gas permeability test matrix resulted in the following conclusions:

- Temperature and humidity are the dominant independent variables.

- The duration of the experiment has a moderate effect.

- Pressure, oxygen content, carbon dioxide content, nitrogen content, and autoclave stirring frequency have negligible effects and may be held constant in all future experimental strategies.

The gas permeability data listed in Table 4 are graphically presented in Figure 3. Changes in gas permeability are shown in the circles as either increasing $(\uparrow)$ or decreasing $(t)$ a certain percentage from the pre-test values. The independent variables represented by the $x, y$, and $z$ axes are temperature, relative humidity, and time, respectively. Each sandstone core was reacted in a dry air environment ( $D)$, a gas-water vapor environment ( $V$ ), or a liquid (ground)-water environment (L). Sumary observations and conclusions for gas permeability tests are as follows: 
TABLE 4. Test Matrix for Screening Experiments

\begin{tabular}{|c|c|c|c|c|c|c|c|c|c|c|c|}
\hline Trial & $\begin{array}{c}\text { Pressure } \\
\text { (bars) }\end{array}$ & $\begin{array}{l}\text { Temperature } \\
\left({ }^{\circ} \mathrm{C}\right)\end{array}$ & $\begin{array}{c}\text { Time } \\
\text { (months) }\end{array}$ & $\begin{array}{c}\text { 0xygen } \\
(\%)\end{array}$ & $\begin{array}{l}\mathrm{CO} 2 \\
(\%)^{2}\end{array}$ & $\begin{array}{l}\text { Stirring } \\
\text { (Yes-No) }\end{array}$ & $\begin{array}{c}\text { Liquid } \\
\text { (Yes-No) }\end{array}$ & $\begin{array}{l}\text { Vapor } \\
\text { (Yes-No) }\end{array}$ & $\begin{array}{r}\text { Permea } \\
(\% \\
\text { Gas } \\
\end{array}$ & $\begin{array}{l}\text { ility } \\
\text { lange) } \\
\text { Liquid } \\
\end{array}$ & $\begin{array}{c}\text { Friability }(1) \\
\text { Index } \\
\text { (\% Change) } \\
\end{array}$ \\
\hline 1 & 120 & 300 & 0.5 & 21 & 0.1 & $Y$ & N & N & $\downarrow 03$ & 00 & $\uparrow 27$ \\
\hline 2 & 120 & 50 & 2.0 & 21 & 0.1 & $N$ & $N$ & N & $\downarrow 02$ & $\downarrow 04$ & $\uparrow 41$ \\
\hline 3 & $60^{(2)}$ & 300 & 2.0 & 21 & 0.0 & $\mathbf{N}$ & $\mathbf{N}$ & $Y$ & $\uparrow 31$ & $\uparrow 78$ & $\uparrow 222$ \\
\hline 4 & 120 & 300 & 2.0 & 0 & 0.0 & $\mathrm{~N}$ & $Y$ & $\mathbf{N}$ & $\uparrow 65$ & $\uparrow 73$ & $\uparrow 474$ \\
\hline 5 & 120 & 300 & 0.5 & 0 & 0.0 & $Y$ & N & $Y$ & $\uparrow 76$ & $\uparrow 38$ & $\uparrow 185$ \\
\hline 6 & 120 & 50 & 0.5 & 0 & 0.1 & $N$ & $Y$ & $Y$ & $\downarrow 17$ & $\uparrow 37$ & +29 \\
\hline 7 & 60 & 50 & 0.5 & 21 & 0.0 & $Y$ & $Y$ & N & $\downarrow 03$ & $\downarrow 08$ & $\uparrow 43$ \\
\hline 8 & 60. & 50 & 2.0 & 0 & 0.1 & $Y$ & N & Y & $\downarrow 18$ & $\uparrow 31$ & $\uparrow 26$ \\
\hline 9 & $60^{(2)}$ & 300 & 0.5 & 21 & 0.1 & N & $Y$ & $Y$ & $\uparrow 96$ & $\downarrow 36$ & $\uparrow 171$ \\
\hline 10 & 120 & 50 & 2.0 & 21 & 0.0 & $Y$ & $Y$ & $Y$ & $\downarrow 11$ & $\uparrow 51$ & $\uparrow 61$ \\
\hline 11 & $60^{(2)}$ & 300 & 2.0 & 0 & 0.1 & $Y$ & $Y$ & N & $\uparrow 12$ & $\uparrow 28$ & $\uparrow 480$ \\
\hline 12 & 60 & 50 & 0.5 & 0 & 0.0 & N & $N$ & $N$ & $\uparrow 02$ & +04 & $\uparrow 31$ \\
\hline
\end{tabular}

(1) Percent change calculated from pre-test and post-test values for each sample.

(2) Actual pressure increased to prevent flashing. 


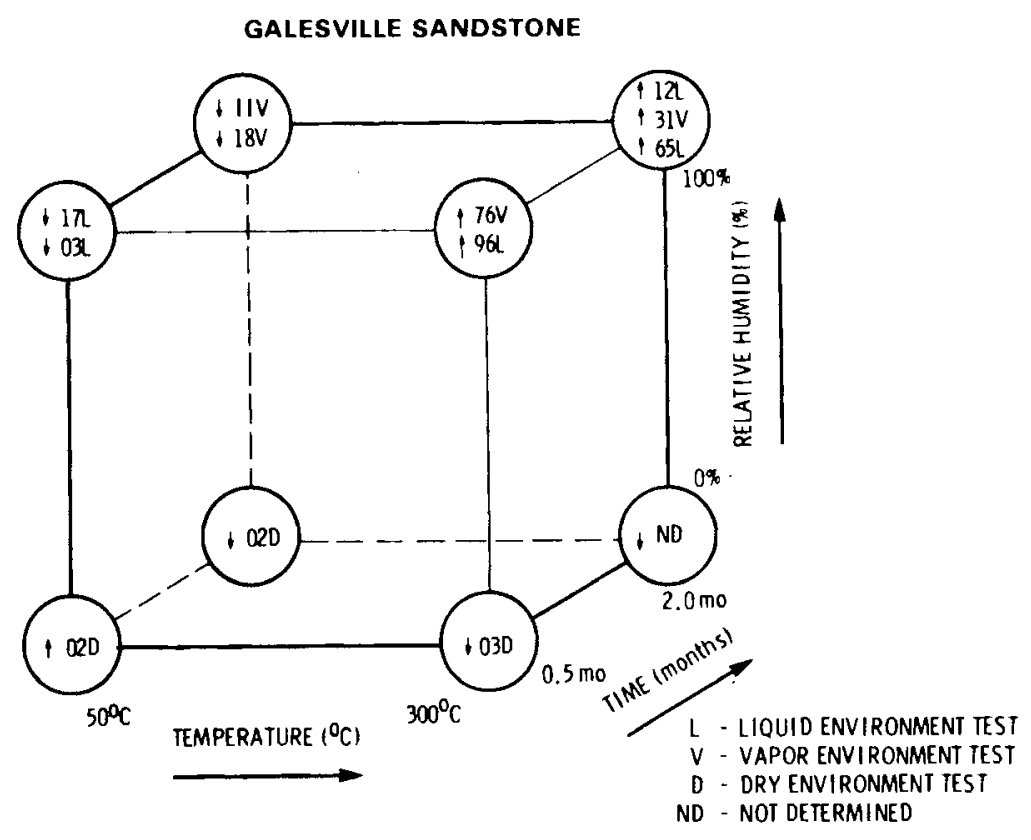

FIGURE 3. Percent Change in Gas Permeability

- The sandstone cores demonstrate good stability with respect to gas permeability if one or both of the following conditions exists; 1) temperatures are $150^{\circ} \mathrm{C}$ or less, and/or 2) water content is negligible.

- The average gas permeability change is approximately $20 \%$ for the environmental conditions of the 12 screening experiments.

- Observed changes in permeability may be attributed, in part, to erosion of the cylindrical core face. This erosion can result in the bypass of gas around the core during the post-test permeability measurement. The erosion may be due to the lack of confining pressure on the sample during the experiment and/or the high ratio of fluid to rock volumes (typical fluid to rock ratio in these experiments was $40: 1$ ).

- The number of experiments and the inhomogeneity of the parent rock core 1 imit the precision of the data. Additional experimental replication is warranted. 


\section{Liquid Permeability}

Liquid permeability data are illustrated in Figure 4. All experimental conditions are identical to those for the gas permeability tests. The analysis of the matrix data gave the following results:

- Temperature, time, and relative humidity are the dominant independent variables.

- Stirring frequency in the autoclave has a moderate effect.

- Oxygen content, nitrogen content, carbon dioxide content, and total interstitial pressure have negligible effects.

- For the range of conditions tested in the screening experiments, the average increase in liquid permeability is approximately $14 \%$, which is similar to that observed for the change in gas permeability.

Matrix Friability

The matrix friability index is designed to measure the shear rupture modulus and grain-to-grain contact strength of sandstone cores before and after treatment at simulated CAES conditions. Figure 5 illustrates the friability data. The following observations were noted from the test matrix results:

- Temperature, time, and humidity are the dominant independent variables.

- Oxygen content and vapor saturation conditions also have moderate effects.

- Pressure, nitrogen content, carbon dioxide content, and stirring frequency are insignificant.

- All combinations of independent variables resulted in an increase in friability and in the disaggregation of the sandstone.

- The lack of confining stress on the cores contributed to the disaggregation of the samples. 


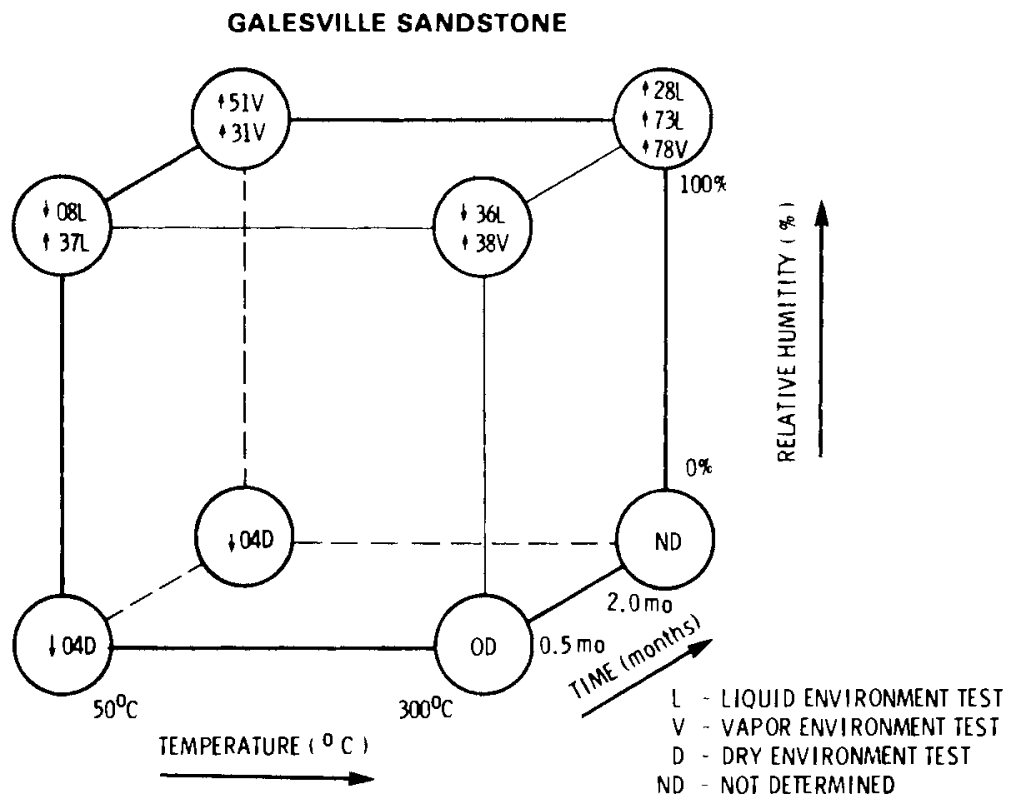

FIGURE 4. Percent Change in Liquid Permeability

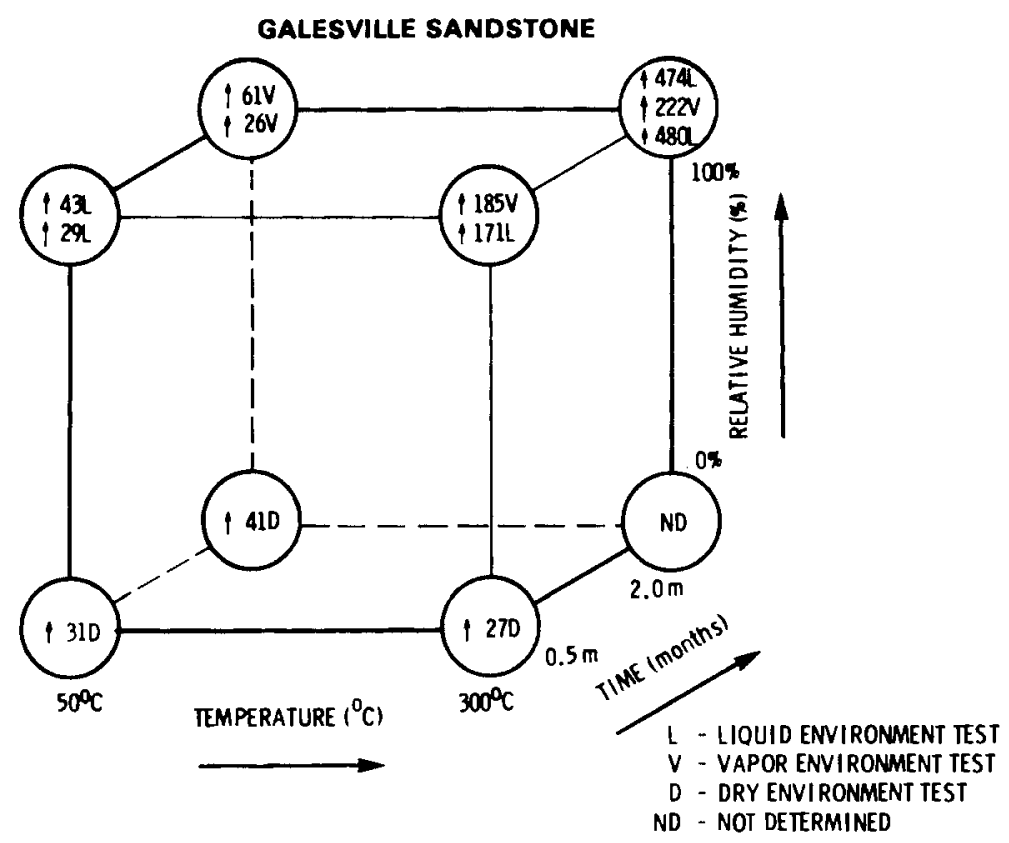

FIGURE 5. Percent Change in Matrix Friability 
- The disaggregation of the sandstone may be caused by dissolution of the interstitial cements (quartz and carbonate). The large ratio of liquid to solid volume probably enhances this chemical reaction. Figures $6 \mathrm{a}$ and $6 \mathrm{~b}$ contrast the varying degress of disaggregation, as a function of temperature and time, that occurred when the Galesville sandstone was subjected to a heated, liquid environment.

\section{DETAILED EXPERIMENTS}

The results of the screening tests indicated that temperature, time, and humidity are the dominant independent variables affecting the stability of the Galesville sandstone. Therefore, these variables were studied in more detail during the second phase of the experimental program. The insignificant independent variables (pressure, $\mathrm{O}_{2}$ content, $\mathrm{N}_{2}$ content, $\mathrm{CO}_{2}$ content, and stirring frequency) were held constant in these experiments.

All experimental results for the Galesville sandstone obtained in this study are 1 isted in Appendix $A$. Included in this Appendix are data for both screening experiments (EXP G-1 to EXP G-14) and detailed tests (EXP G-15 to EXP G-42). Beginning with experiment G-22, note that: 1) apparent porosity was selected as a dependent variable in addition to gas permeability, water permeability, and friability; and 2) two cores were reacted simultaneously. Simultaneous reaction of two cores per experiment improved the statistics of the dependent variable measurements. Only a maximum of two cores could simultaneously be reacted per autoclave because of the size limitations of the pressure vessels.

Physical Responses

The disaggregation observed (Figure 6) during the screening and detailed tests for some sandstone samples reacted in humid gas above $200^{\circ} \mathrm{C}$ was somewhat unexpected. If dissolution of quartz is mainly responsible for changes in physical rock properties and disaggregation of the cores, sandstone reacted in gas-water vapor mixtures should exhibit smaller changes in these properties than in 100\% liquid experiments. This result is expected since the solubility of quartz in water vapor is immeasurably small relative to its solubility in 


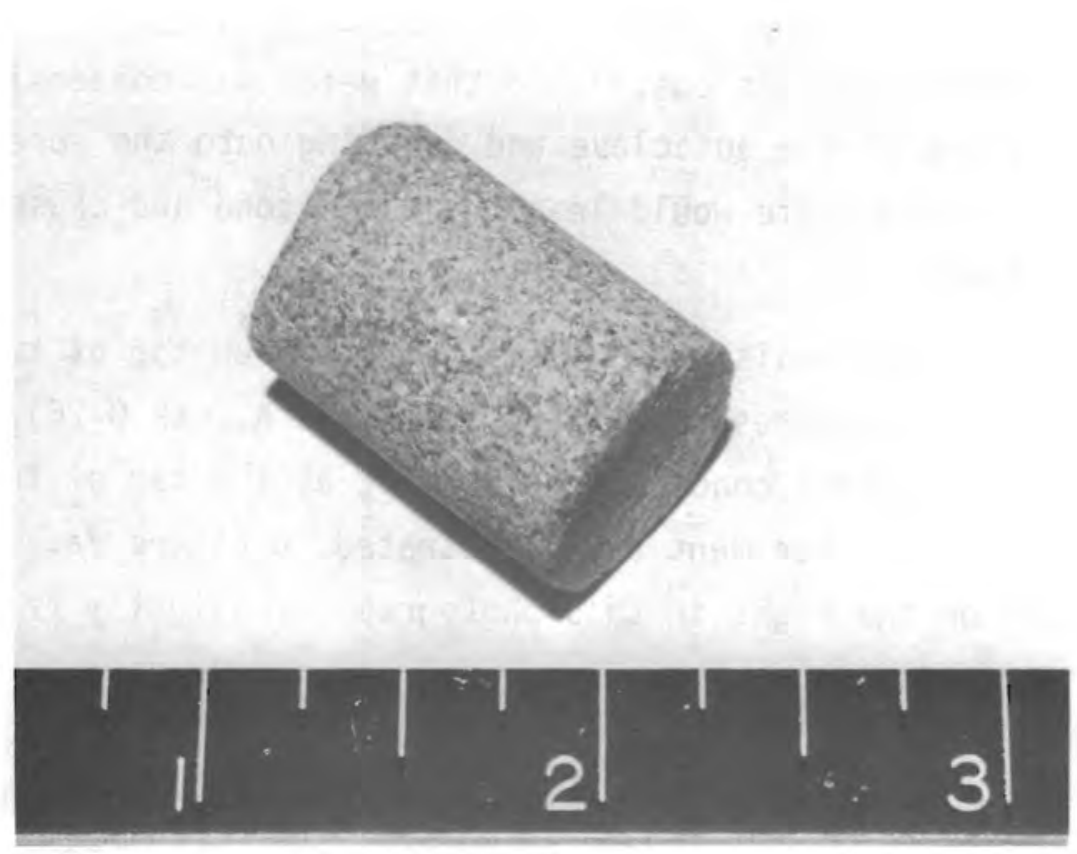

a. $50^{\circ} \mathrm{C}, 336$ hours, Liquid

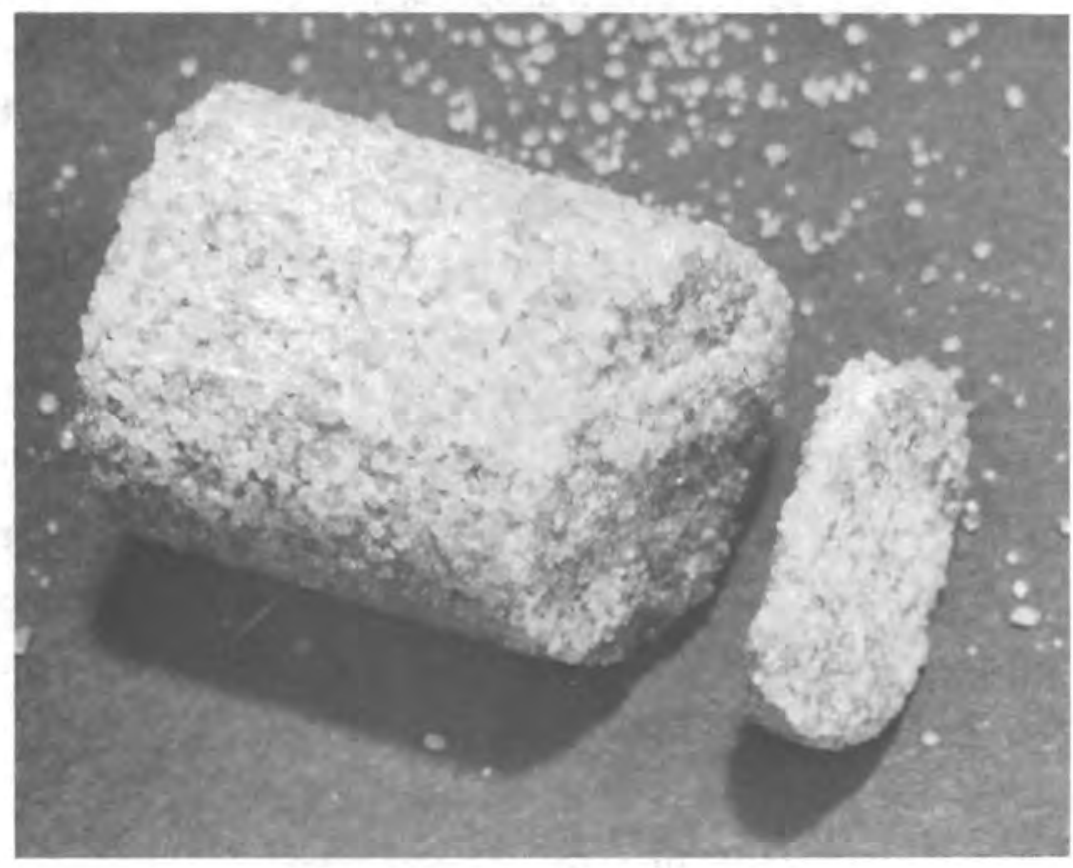

b. $300^{\circ} \mathrm{C}, 1488$ hours, Liquid

FIGURE 6. Increasing Disaggregation of Galesville Samples Reacted in a High Humidity Environment at Elevated Temperatures 
liquid water at temperatures and pressures below the critical point of water (Kennedy, 1950). Therefore, it was postulated that water was condensing above the core in cooler regions of the autoclave and dripping onto the core. If such were the case, the condensate would leach the sandstone and cause extensive surface disaggregation.

To investigate this hypothesis, gold foil was folded on top of two cores before they were placed in the pressure vessel (Appendix A, EXP G-26). The foil shielded the cores from any condensation forming at the top of the autoclave. The results of this experiment are illustrated in Figure $7 \mathrm{a}$. The surface of the core (J13) on the right in this photograph is slightly friable compared to the extensive surface pitting and spalling of grains present in unshielded cores reacted under identical conditions (e.g., Figure 7b). The core on the left in Figure 7a (J19) exhibits obvious pitting and disaggregation over a small area of the core. As seen in the photograph, the gold foil was placed above the core with part of the foil in direct contact with the core. Because of improper shielding, water was transported from the area of contact along the length of the core. As a consequence, the surface pitting resulted. The shielded portion of this core exhibited no evidence of disaggregation.

Because the disaggregation appeared to be an experimental difficulty, some doubt remained as to the validity of the post-experiment physical properties measured on unshielded cores. Therefore, in experiments involving reaction of sandstone cores in the vapor phase conducted after experiment G-26, gold foil shields were used to prevent this anomalous disaggregation.

Figures 8 through 11 illustrate the response of each of the dependent variables as a function of temperature and humidity. In these figures, a distinction is made between shielded and unshielded cores reacted in a humidified air environment. The experimental results in Figures 10 and 11 indicate that porosity and friability increased in all simulated CAES environments. In contrast, both increases and decreases in rock gas and water permeability were noted in these experiments (Figures 8 and 9). Small changes in a11 physical properties were measured at temperatures less than or equal to $150^{\circ} \mathrm{C}$. Changes in gas permeability, water permeability, and porosity increased at a greater 


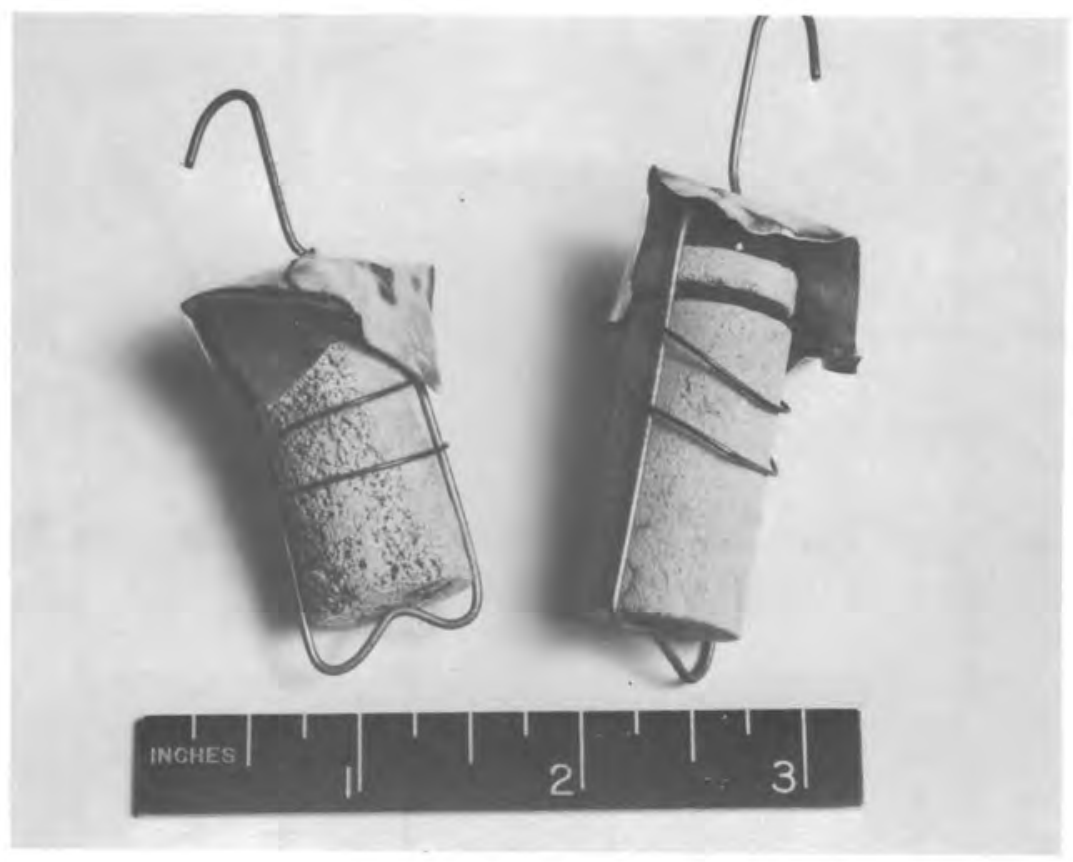

a.

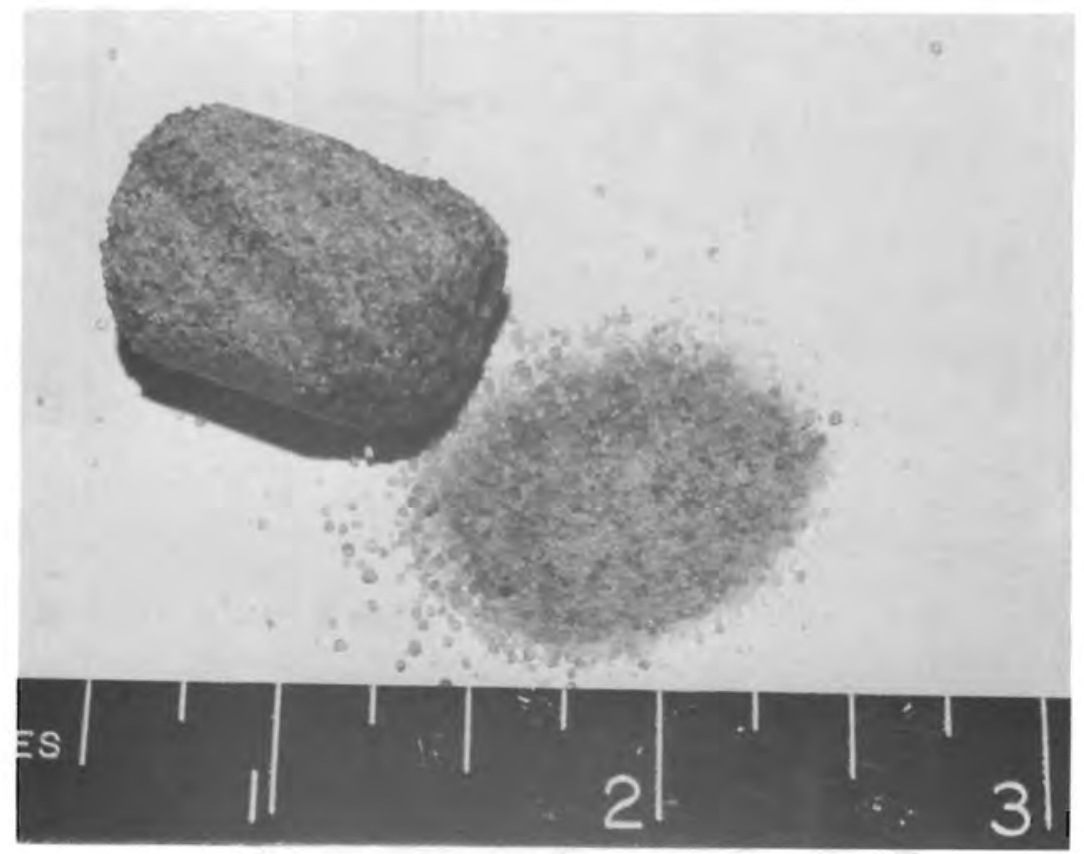

b.

FIGURE 7. Results of a) Experiment G-26 (Cores J-19 and J-13), Run Conditions are $300^{\circ} \mathrm{C}$, Vapor, 355 Hours, and b) Experiment G-5, Core D-5, Run Conditions are $300^{\circ} \mathrm{C}$ Vapor, 360 Hours, Core Unshielded 


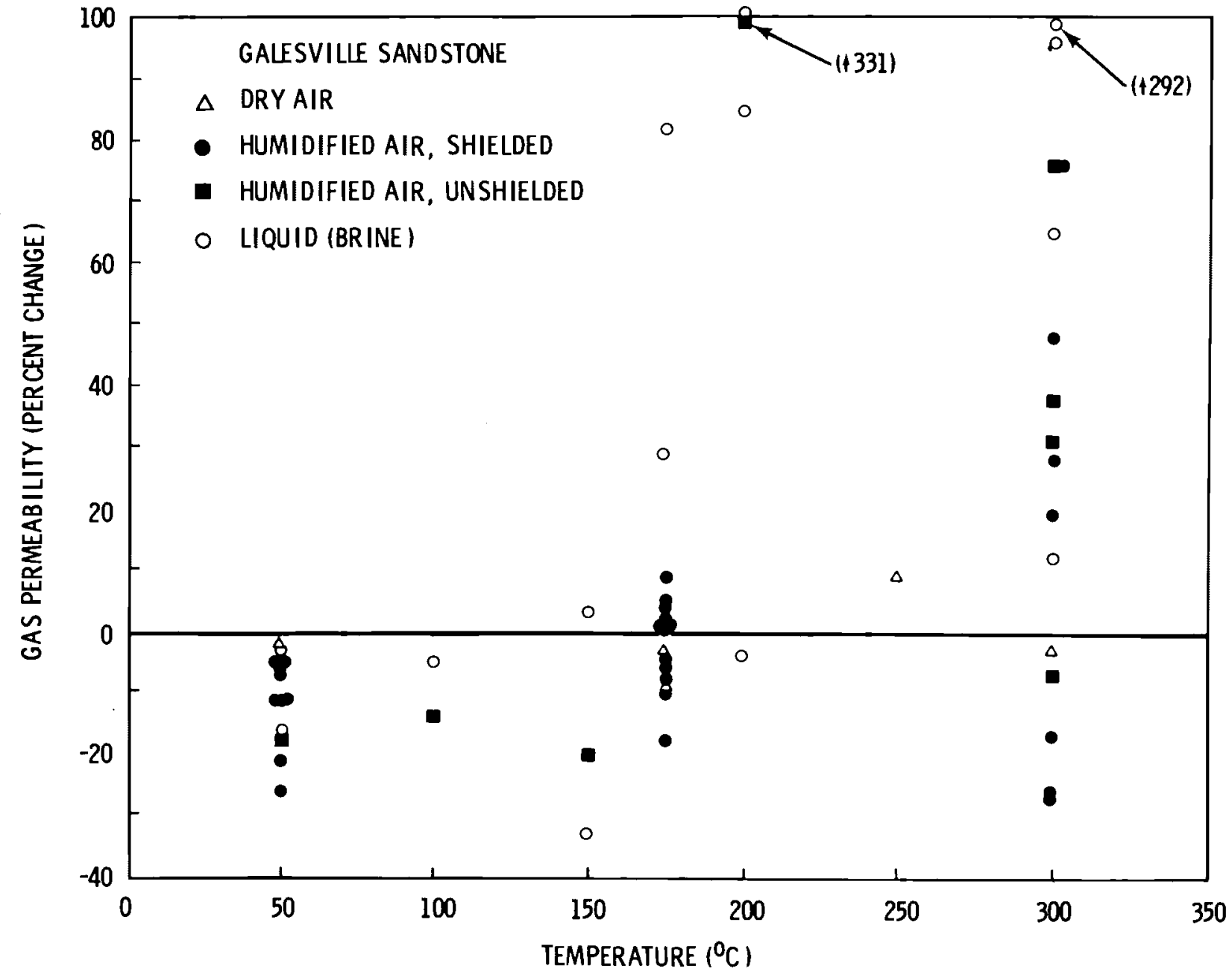

FIGURE 8. Percent Change in Gas Permeability with Temperature 


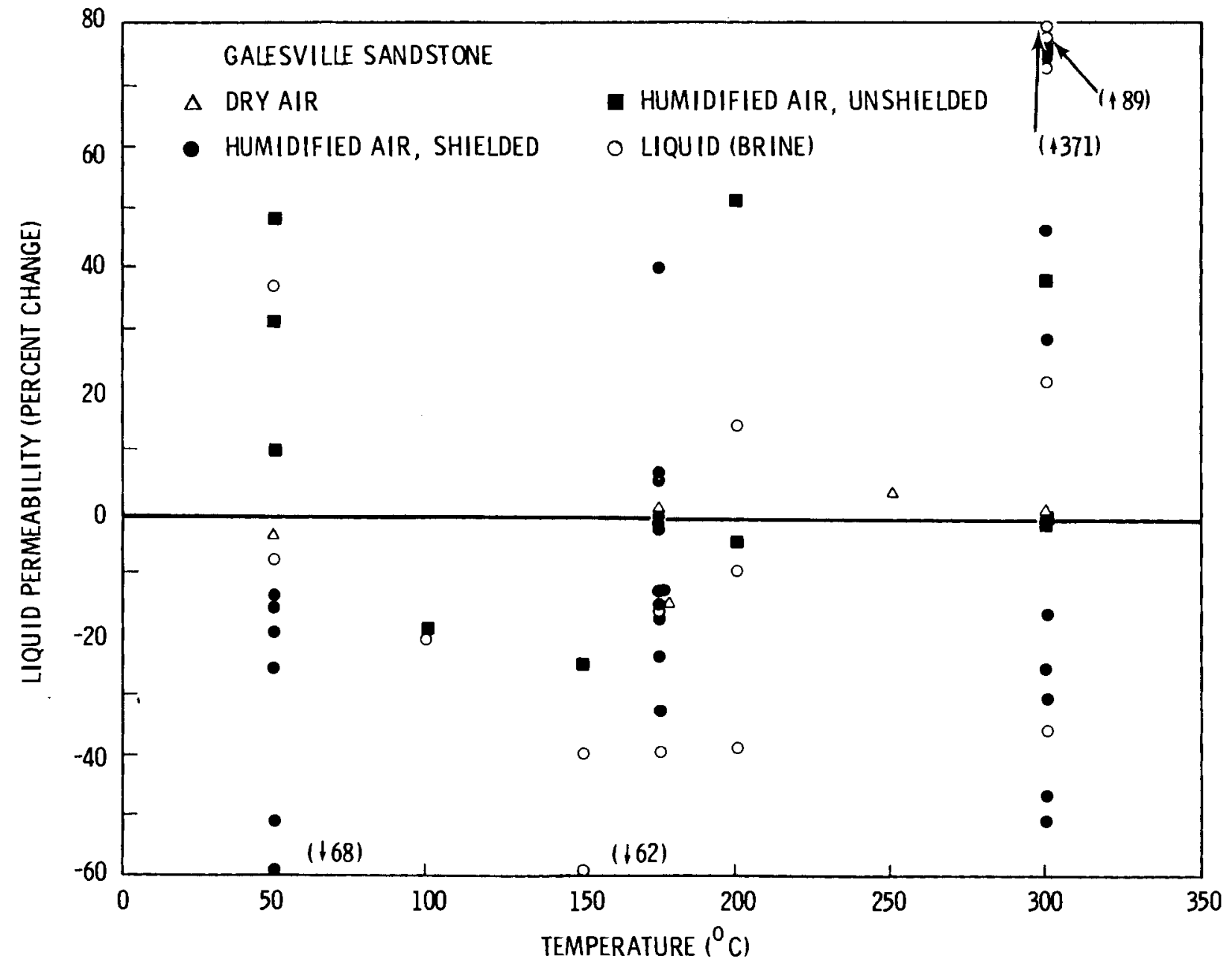

FIGURE 9. Percent Change in Water Permeability with Temperature 


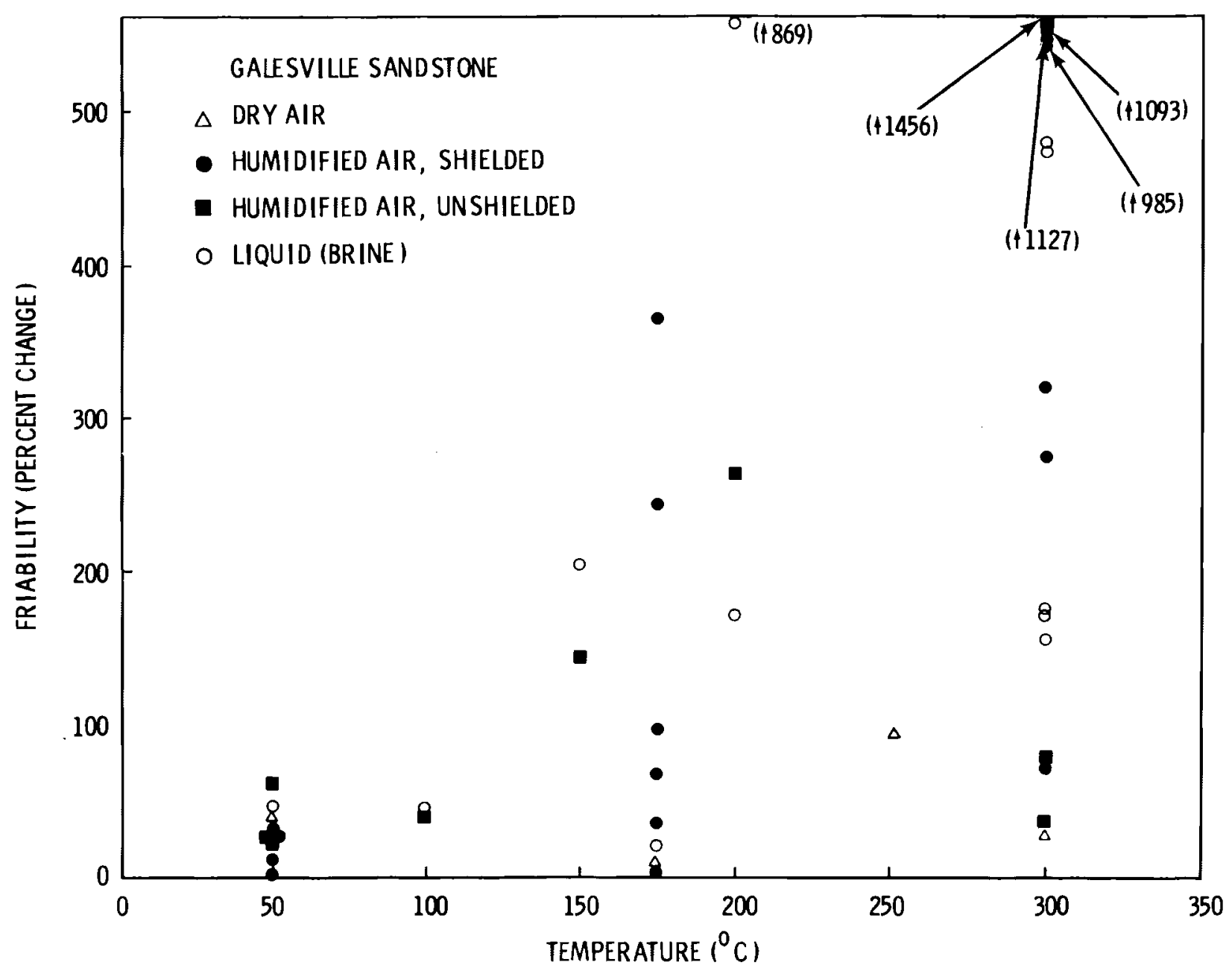

FIGURE 10. Percent Change in Friability with Temperature 


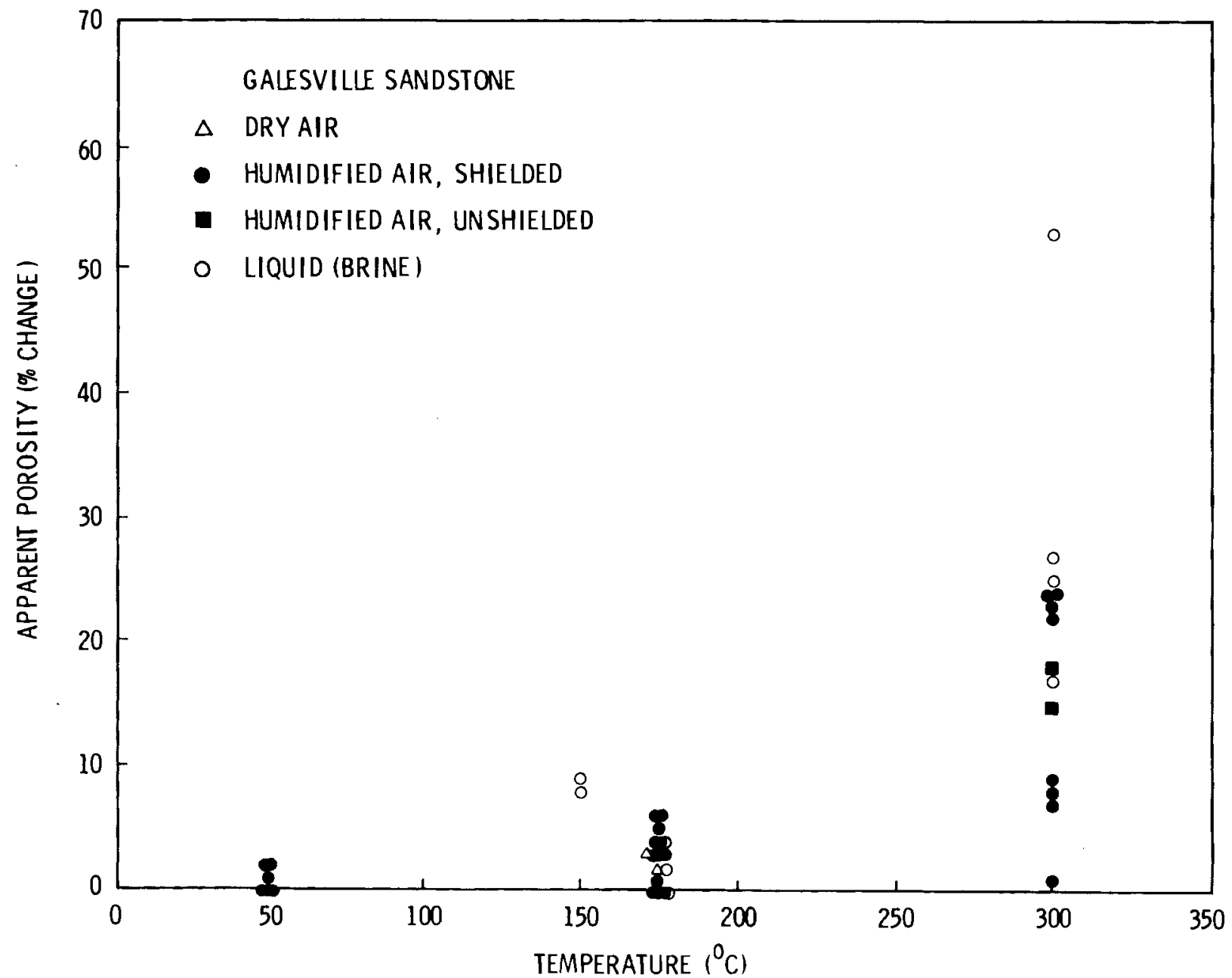

FIGURE 11. Percent Change in Apparent Pososity with Temperature 
rate above $150^{\circ} \mathrm{C}$. Values for friability exhibited a marked increase between $150^{\circ}$ and $300^{\circ} \mathrm{C}$. Overa 11 , the greatest changes in physical properties occurred in those cores reacted in a liquid environment. However, this is the least likely environment to be encountered in an elevated temperature CAES reservoir. An important trend in the data is that insignificant changes in all physical properties were observed for $0 \%$ humidity (dry air) conditions, regardless of the temperature of the experiment. For the most part, similar observations were made for shielded cores reacted in water vapor environments.

Much of the experimental scatter in the data is the result of disaggregation of samples under conditions of high humidity and high temperature conditions. Many difficulties were encountered obtaining accurate measurements of physical properties for these delicate samples. In some cases, due to extensive disaggregation, no measurements could be obtained (indicated as ND in Appendix A). Therefore, changes in permeability or degradation of the Galesville sandstone under simulated CAES conditions cannot be accurately predicted if based solely on the data obtained in the autoclave experiments. The porous media flow facility currently being fabricated will eliminate many of the restrictions of the autoclave experiments. In this new facility, an accurate simulation of anticipated CAES environments will be possible and changes in many of the fluid flow and structural properties of the sandstone will be continuously monitored during the elevated temperature experiments.

Chemical Responses

The groundwater present in the autoclaves was sampled during several experiments in which sandstone was reacted in liquid. Table 5 lists the determined groundwater chemical compositions at the conclusion of six experiments. The sampling method and analytical techniques are summarized in Appendix B. The major water/rock interaction implied by the fluid chemistry data (Table 5) is dissolution of quartz as a function of temperature and time. Figures 12 and 13 illustrate the changes in concentration with time of the elements $\mathrm{Ca}$, $\mathrm{Mg}, \mathrm{Si}, \mathrm{K}$, and $\mathrm{Na}$ in the fluid reacted with the Galesville sandstone at $50^{\circ}$ and $300^{\circ} \mathrm{C}$, respectively. The curves represent eye fits to the experimental data and are included only to identify general trends. The data for Si concentration in Table 5 illustrate the positive correlation between concentration 
TABLE 5. Chemical Composition of Groundwater

\begin{tabular}{|c|c|c|c|c|c|c|c|c|c|c|c|c|c|c|}
\hline & Core & & & Time & \multicolumn{8}{|c|}{ Elemental Concentrations $(\mathrm{mg} / \mathrm{l})$} & \multirow{2}{*}{$\begin{array}{c}\text { Solution } \\
\mathrm{pH} \\
\end{array}$} \\
\hline & & No. & $\mathrm{T}^{\circ} \mathrm{C}$ & $\underline{P(\text { bars })}$ & (hours) & $\mathrm{Si}$ & $\underline{\mathrm{Ca}}$ & $\mathrm{Mg}$ & $\mathrm{Na}$ & $\mathrm{K}$ & $\mathrm{Cr}$ & $\mathrm{Fe}$ & $\mathrm{Mn}$ & \\
\hline & \multicolumn{5}{|c|}{ INITIAL GROUNDWATER } & $<0.05$ & 50 & 14 & 430 & 200 & 0 & 0 & 0 & 8.0 \\
\hline & G-8 & $\mathrm{D}-8$ & 50 & 60 & 357 & 6 & 29 & 12 & 486 & 251 & $<0.05$ & 0.2 & $<0.05$ & 7.5 \\
\hline & G-11 & $I-16$ & 50 & 60 & 335 & 1.7 & 50 & 11.5 & 444 & 238 & 0.3 & 0.3 & $<0.05$ & 8.12 \\
\hline & G-16 & D-13 & 200 & 120 & 238 & 76 & 25.5 & 0.2 & 447 & 223 & $<0.05$ & $<0.05$ & $<0.05$ & - \\
\hline & G-1 & $D-3$ & $300^{\circ}$ & 120 & 335 & 201 & 13 & 3.1 & 443 & 196 & 45 & 1.1 & 0.05 & 6.66 \\
\hline & G-6 & $D-6$ & 300 & 120 & 1457 & 193 & 0.6 & $<0.05$ & 454 & 185 & 0.03 & $<0.05$ & $<0.05$ & 8.40 \\
\hline & $G-7^{(1)}$ & $D-4$ & 300 & 120 & 2392 & 206 & 0.5 & $<0.05$ & 291 & 115 & 51.1 & 0.2 & $<0.05$ & 8.08 \\
\hline
\end{tabular}

(1) Composition determined from sample collected after 1968 hours 


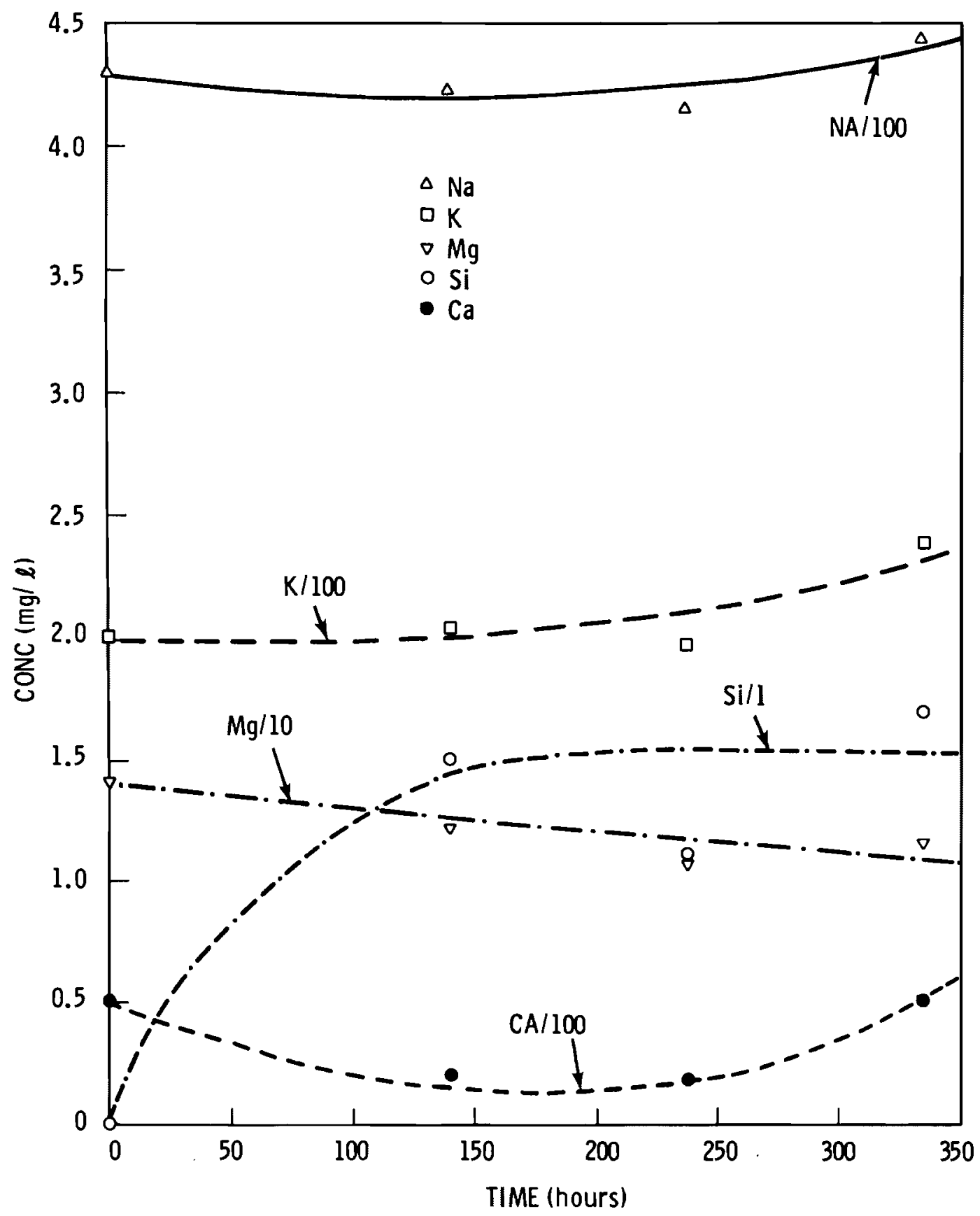

FIGURE 12. Elemental Fluid Concentrations (mg/1) Versus Time for EXP G-11 


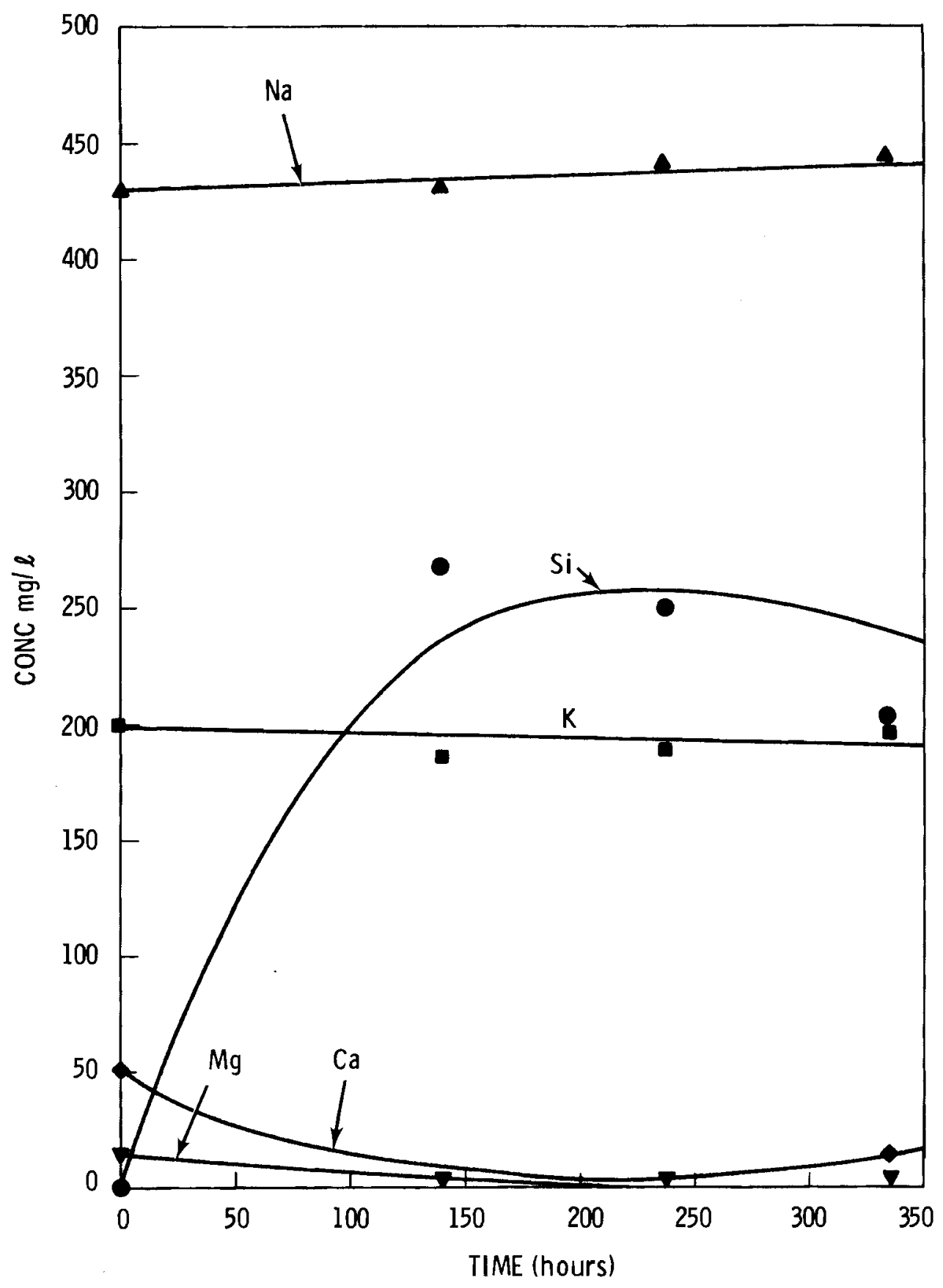

FIGURE 13. Elemental Fluid Concentrations (mg/l) Versus Time for EXP G-1 
and temperature. The changes in concentration with time of $\mathrm{Ca}, \mathrm{Mg}, \mathrm{Na}$, and $\mathrm{K}$ (Figures 12 and 13) are considered insignificant. However, the concentration of $\mathrm{Si}$ exhibits an initial rapid increase and approaches a constant value. In addition, the concentration of $\mathrm{Si}$ in the fluid at $300^{\circ} \mathrm{C}$ is significantly greater than at $50^{\circ}$ or $200^{\circ} \mathrm{C}$. The concentrations of two anionic species in the fluid were also determined but are considered insignificant. Typical concentrations determined for $\mathrm{SO}_{4}^{2-}$ at $50^{\circ}$ and $300^{\circ} \mathrm{C}$ were $240 \mathrm{mg} / 1$ and $200 \mathrm{mg} / 1$, respectively, and $138 \mathrm{mg} / 1$ for $\mathrm{CO}_{3}^{2-}$ at $300^{\circ} \mathrm{C}$. The concentrations of $\mathrm{SO}_{4}^{2-}$ and $\mathrm{CO}_{3}^{2-}$ in the initial groundwater were $300 \mathrm{mg} / 1$ and $150 \mathrm{mg} / 1$, respectively.

Since the Galesville sandstone is composed of nearly 100\% quartz, no major chemical reactions, other than dissolution of quartz in the aqueous fluid, were anticipated in the pressure-temperature range of this study. Evidence from thin sections, photomicrographs, X-ray diffractograms, and X-ray fluorescence analys is of reacted Galesville sandstone indicates that no observable mineral alterations occurred, even at high temperatures. X-ray diffractograms of unreacted material and cores D-5 (EXP G-5) and D-3 (EXP G-1) suggest only $\alpha$-quartz is present (Table 6). Bulk chemical analyses of reacted and unreacted Galesville sandstone obtained by $X$-ray fluorescence also imply no perceptible change in the bulk rock chemistry (Table 7 ). Comparison of Figures $2 a$ and $b$ with Figures $14 a$ and $b$ illustrates that the trace amounts of calcite present in the unreacted material have disappeared, presumably dissolved in the fluid phase. Although data for the fluid geochemistry imply quartz dissolution, concentrations of silicon in the fluid are so small at these experimental temperatures and test durations that there is no observed petrographic evidence for quartz dissolution. 
TABLE 6. Comparative X-ray Diffraction Data for Unreacted Galesville Sandstone and Cores D-5 and D-3

\begin{tabular}{|c|c|c|c|c|c|c|c|}
\hline \multicolumn{2}{|c|}{$\begin{array}{l}\text { Unreacted Gales- } \\
\text { ville Sandstone }\end{array}$} & \multicolumn{2}{|c|}{$\begin{array}{r}\text { Reacted fore } \\
D-5(1)\end{array}$} & \multicolumn{2}{|c|}{$\begin{array}{c}\text { Reacted fore } \\
D-3(2)\end{array}$} & \multicolumn{2}{|c|}{$\alpha$-Quartz (3) } \\
\hline $\mathrm{d} \AA$ & $\begin{array}{l}\text { Relative } \\
\text { Intensity }\end{array}$ & $d \AA$ & $\begin{array}{l}\text { Relative } \\
\text { Intensity }\end{array}$ & $\mathrm{d} \AA$ & $\begin{array}{l}\text { Relative } \\
\text { Intensity }\end{array}$ & $\mathrm{dA}$ & $\begin{array}{l}\text { Relative } \\
\text { Intensity }\end{array}$ \\
\hline 4.23 & 30 & 4.25 & 25 & 4.23 & 24 & 4.26 & 35 \\
\hline 3.336 & 100 & 3.336 & 100 & 3.327 & 100 & 3.343 & 100 \\
\hline 2.533 & 2 & 2.540 & 2 & - & - & - & - \\
\hline 2.447 & 15 & 2.453 & 14 & 2.453 & 13 & 2.458 & 12 \\
\hline 2.268 & 14 & 2.274 & 11 & 2.274 & 13 & 2.282 & 12 \\
\hline 2.225 & 9 & 2.231 & 7 & 2.231 & 11 & 2.237 & 6 \\
\hline 2.120 & 13 & 2.120 & 10 & 2.120 & 11 & 2.128 & 9 \\
\hline 2.079 & 2 & 2.079 & 2 & - & - & - & - \\
\hline 1.971 & 8 & 1.975 & 6 & 1.975 & 10 & 1.980 & 6 \\
\hline 1.809 & 25 & 1.812 & 22 & 1.816 & 10 & 1.817 & 17 \\
\hline 1.665 & 10 & 1.668 & 7 & 1.668 & 10 & 1.672 & 7 \\
\hline 1.654 & 4 & 1.657 & 4 & - & - & 1.659 & 3 \\
\hline 1.604 & 2 & 1.601 & 2 & - & - & 1.608 & 1 \\
\hline 1.596 & 2 & - & - & - & - & - & - \\
\hline 1.536 & 18 & 1.538 & 15 & 1.538 & 15 & 1.541 & 15 \\
\hline
\end{tabular}

(1) Run Conditions: $300^{\circ} \mathrm{C}, 120$ bars, 360 hours in air-water vapor mixture

(2) Run Conditions: $300^{\circ} \mathrm{C}, 120$ bars, 335 hours in liquid water

(3) Joint Committee of Powder Diffraction Standards (JCPDS) File Card No. 5-490. 
TABLE 7. Comparative X-Ray Fluorescence Data(1) for Sandstone Cores D-4 and D-5

\begin{tabular}{|c|c|c|c|}
\hline Oxide & $\begin{array}{c}\text { Unreacted } \\
\text { Galesville } \\
\text { Sandstone } \\
\text { wt\% }\end{array}$ & $\begin{array}{l}\text { Reacted } \\
\text { Core } \\
\text { D-4(2) } \\
\text { wt\% } \\
\end{array}$ & $\begin{array}{l}\text { Reacted } \\
\text { Core } \\
\text { D-5(3) } \\
\text { wt\% } \\
\end{array}$ \\
\hline $\mathrm{SiO}_{2}$ & 99.20 & 99.51 & 99.42 \\
\hline $\mathrm{Al}_{2} \mathrm{O}_{3}$ & 0.19 & 0.11 & 0.09 \\
\hline $\mathrm{TiO}_{2}$ & 0.01 & 0.01 & 0.01 \\
\hline $\mathrm{Fe}_{2} \mathrm{O}_{3}$ * & 0.02 & 0.00 & 0.01 \\
\hline $\mathrm{Fe} 0 *$ & 0.03 & 0.00 & 0.01 \\
\hline Mno & 0.00 & 0.00 & 0.00 \\
\hline $\mathrm{CaO}$ & 0.05 & 0.01 & 0.00 \\
\hline $\mathrm{MgO}$ & 0.12 & 0.11 & 0.11 \\
\hline $\mathrm{K}_{2} \mathrm{O}$ & 0.04 & 0.02 & 0.00 \\
\hline $\mathrm{Na}_{2} \mathrm{O}$ & 0.34 & 0.21 & 0.32 \\
\hline \multirow[t]{2}{*}{$\mathrm{P}_{2} \mathrm{O}_{5}$} & 0.01 & 0.02 & 0.03 \\
\hline & 100.01 & 100.00 & 100.00 \\
\hline
\end{tabular}

(1) Analyses performed by the Department of Geology, Washington State University, Pullman, Washington. All analyses normalized on a volatile-free basis.

(2) Run Conditions: $300^{\circ} \mathrm{C}, 120$ bars, 2392 hours in liquid water.

(3) Run Conditions: $300^{\circ} \mathrm{C}, 120$ bars, 360 hours in air-water vapor mixture.

* Total iron recorded as $44 \% \mathrm{Fe}_{2} \mathrm{O}_{3}$, $56 \% \mathrm{Fe} 0$. 


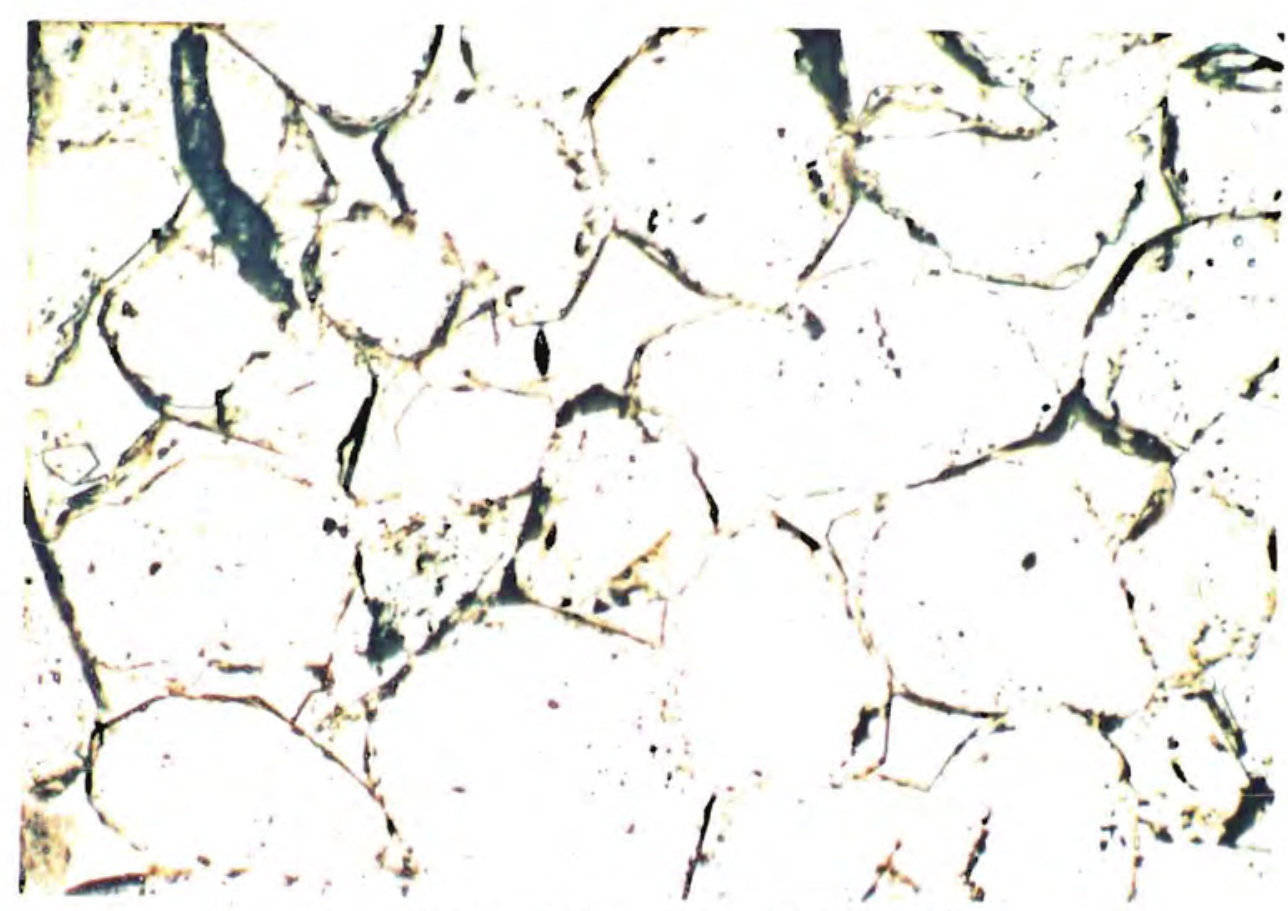

a. Plane Polarized Light (50X)

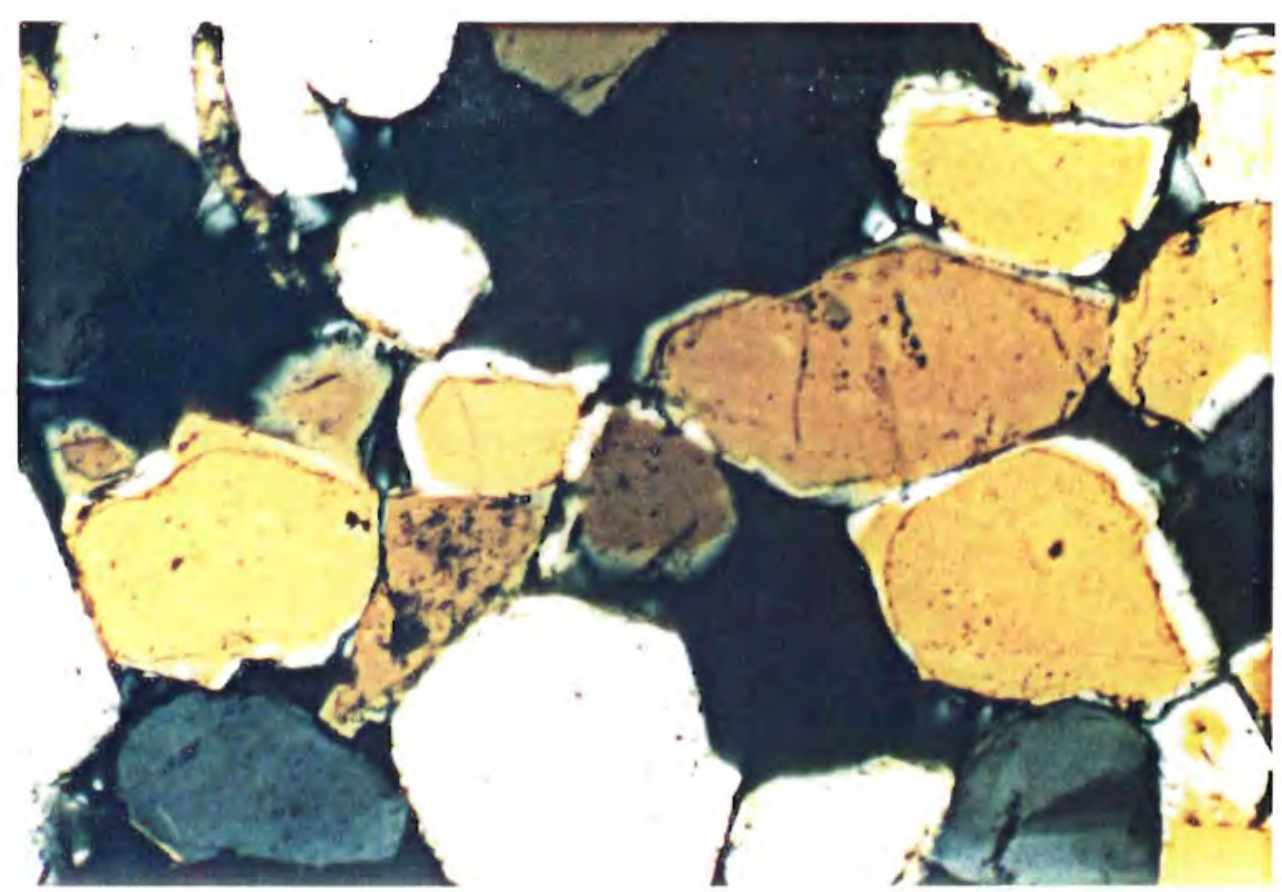

b. Crossed Nicols (50X)

FIGURE 14. Galesville Sandstone After Heating to $300^{\circ} \mathrm{C}$ in an Air-Water Vapor Mixture 
. 


\section{REFERENCES}

Franklin, J. A. 1972. "Suggested Methods for Determining Water Content, Porosity, Density, Absorption and Related Properties and Swelling and Slake-Durability Index Properties," Commission on Standardization of Laboratory and Field Tests, International Society for Rock Mechanics.

Kennedy, G. C. 1950. A Portion of the System Silica-Water. Economic Geology, $45: 629-653$.

Plackett, R. L. and J. P. Burman. 1946. The Design of Optimum Multifactorial Experiments. Biometrika, 133:305-325.

Reeve, R. C. 1965. "Modulus of Rupture," Methods of Soil Analys is, Part 1, C. A. Black ed., Amer. Soc. of Agronomy, Madison, Wisconsin. 
.

. 
APPENDIX A

EXPERIMENTAL DATA FOR GALESVILLE SANDSTONE 
APPENDIX A

EXPERIMENTAL DATA FOR GALESVILLE SANDSTONE

\begin{tabular}{|c|c|c|c|c|c|c|c|c|c|}
\hline $\begin{array}{l}\text { Run } \\
\text { No. }\end{array}$ & $\begin{array}{c}\text { Core } \\
\text { No. }\end{array}$ & $\mathrm{T}^{\circ} \mathrm{C}$ & $\underline{P(\text { bars })}$ & $\begin{array}{c}\text { Time } \\
\text { (hours) }\end{array}$ & $\begin{array}{l}\text { Liquid(L) } \\
\text { Vapor }(V) \\
\text { or } \operatorname{Dry}(D) \\
\end{array}$ & $\begin{array}{l}\text { Change } \\
\text { in } \\
\mathrm{K}_{\mathrm{GAS}}(\boldsymbol{\xi})\end{array}$ & $\begin{array}{l}\text { Change } \\
\text { in } \\
\underline{K}_{L I Q U I D}(\boldsymbol{q})^{(3)}\end{array}$ & $\begin{array}{c}\begin{array}{c}\text { Change } \\
\text { in }\end{array} \\
\text { Friability }(\%) \\
\end{array}$ & $\begin{array}{c}\begin{array}{c}\text { Change } \\
\text { in }\end{array} \\
\text { Porosity }(\%) \\
\end{array}$ \\
\hline$G-1$ & $D-3$ & 300 & 120 & 335 & L & $\uparrow 96$ & $\downarrow 36$ & $\uparrow 171$ & - \\
\hline G-2 & $D-1$ & 50 & 60 & 338 & $v$ & +6 & $\uparrow 10$ & $\uparrow 24$ & - \\
\hline G-4 & $D-2$ & 300 & 120 & 338 & $v$ & $\uparrow 76$ & $\uparrow 38$ & $\uparrow 185$ & - \\
\hline G-5 & $D-5$ & 300 & 120 & 360 & $v$ & $\uparrow 31$ & $\uparrow 78$ & $\uparrow 222$ & - \\
\hline G-6 & $D-6$ & 300 & 120 & 1457 & $L$ & $\uparrow 12$ & $\uparrow 28$ & $\uparrow 480$ & - \\
\hline G-7 & $D-4$ & 300 & 120 & 2392 & L & $\uparrow 65$ & $\uparrow 73$ & $\uparrow 474$ & - \\
\hline G-8 & $D-8$ & 50 & 60 & 357 & L & +17 & $\uparrow 37$ & $\uparrow 29$ & - \\
\hline G-9 & $D-7$ & 50 & 60 & 1440 & $v$ & $\$ 18$ & $\uparrow 31$ & $\uparrow 26$ & - \\
\hline G-11 & $I-16$ & 50 & 60 & 335 & $L$ & +3 & $\$ 8$ & $\uparrow 43$ & - \\
\hline G-12 & $D-9$ & 50 & 120 & 2904 & $v$ & $\downarrow 11$ & $\uparrow 51$ & $\uparrow 61$ & - \\
\hline G-13 & $D-10$ & 300 & 120 & 330 & $D$ & +3 & 0 & $\uparrow 27$ & - \\
\hline G-14 & $D-11$ & 50 & 120 & 330 & $D$ & +2 & +4 & $\uparrow 41$ & - \\
\hline G-15 & $. D-12$ & 200 & 120 & 339 & v & $\uparrow 331$ * & $\uparrow 51$ & ND & - \\
\hline G-16 & $D-13$ & 200 & 120 & 238 & $L$ & $\uparrow 100 \star$ & $\$ 10$ & $\uparrow 171$ & - \\
\hline G-17 & $D-14$ & $250-300^{(1)}$ & $75-120$ & & $D$ & 49 & $\uparrow 3$ & $\uparrow 93$ & - \\
\hline G-18 & $\mathrm{J}-1$ & 100 & 60 & 340 & L & $\$ 5$ & $\downarrow 21$ & +45 & - \\
\hline G-19 & $J-2$ & 100 & 60 & 341 & v & $\downarrow 14$ & $\downarrow 20$ & $\$ 40$ & - \\
\hline G-20 & $J-3$ & 150 & 60 & 340 & v & $\downarrow 20$ & $\downarrow 25$ & $\uparrow 145$ & - \\
\hline G-21 & $J-4$ & 200 & 60 & 340 & v & 0 & $\$ 5$ & $\uparrow 265$ & - \\
\hline G-22 & $J-6$ & 300 & 120 & 456 & v & $\downarrow 7$ & $\downarrow 2$ & $\uparrow 1456$ & $\uparrow 18$ \\
\hline G-22 & $\mathrm{J}-10$ & 300 & 120 & 456 & $v$ & $\uparrow 38$ & $\downarrow 1$ & & $\uparrow 15$ \\
\hline G-23 & J-5 & 300 & 120 & 411 & L & $\uparrow 296 \star$ & $\uparrow 89$ & $\uparrow 173$ & $\uparrow 17$ \\
\hline
\end{tabular}


EXPERIMENTAL DATA FOR GALESVILLE SANDSTONE (contd)

\begin{tabular}{|c|c|c|c|c|c|c|c|c|c|}
\hline $\begin{array}{l}\text { Run } \\
\text { No. }\end{array}$ & $\begin{array}{l}\text { Core } \\
\text { No. }\end{array}$ & $T^{\circ} \mathrm{C}$ & $\underline{P(\text { bars })}$ & $\begin{array}{c}\text { Time } \\
\text { (hours) } \\
\end{array}$ & $\begin{array}{l}\text { Liquid(L) } \\
\operatorname{Vapor}(V) \\
\text { or } \operatorname{Dry}(D) \\
\end{array}$ & $\begin{array}{l}\text { Change } \\
\text { in } \\
\underline{K}_{G A S}(\%)^{(2)}\end{array}$ & $\begin{array}{l}\text { Change } \\
\quad \text { in } \\
\underline{K}_{\text {LIQUID }}(\boldsymbol{q})^{(3)}\end{array}$ & $\begin{array}{c}\begin{array}{c}\text { Change } \\
\text { in }\end{array} \\
\text { Friability }(\%) \\
\end{array}$ & $\begin{array}{c}\begin{array}{c}\text { Change } \\
\text { in }\end{array} \\
\text { Porosity }(\%) \\
\end{array}$ \\
\hline G-23 & $\mathrm{J}-8$ & 300 & 120 & 411 & L & ND & ND & & $\uparrow 53 \star$ \\
\hline$G-24$ & $J-7$ & 150 & 120 & 410 & L & $\downarrow 33$ & $\downarrow 62$ & $\uparrow 205$ & $\uparrow 9$ \\
\hline G-24 & $\mathrm{J}-12$ & 150 & 120 & 410 & L & $\uparrow 3$ & $\downarrow 40$ & & $\uparrow 8$ \\
\hline G-25 & $J-9$ & $200-300^{(1)}$ & $50-120$ & 456 & $\mathrm{~L}$ & $\uparrow 85$ & $\uparrow 14$ & $\uparrow 869$ & $\uparrow 27$ \\
\hline G-25 & $\mathrm{J}-11$ & $200-300^{(1)}$ & $50-120$ & 456 & $\mathrm{~L}$ & $\downarrow 4$ & $\downarrow 39$ & & $\uparrow 2$ \\
\hline G-26 & $\mathrm{J}-13$ & 300 & 120 & 355 & v & $\downarrow 17$ & $\downarrow 26$ & $\uparrow 71$ & $\uparrow 24$ \\
\hline G-26 & $\mathrm{J}-19$ & 300 & 120 & 355 & $v$ & ND & ND & & ND \\
\hline G-27 & $\mathrm{J}-14$ & 50 & 120 & 1343 & v & $\downarrow 5$ & $\downarrow 51$ & $\uparrow 33$ & $\uparrow 2$ \\
\hline G-27 & $J-20$ & 50 & 120 & 1343 & v & $\downarrow 5$ & $\downarrow 14$ & & 0 \\
\hline G-28 & $\mathrm{J}-15$ & 50 & 120 & 335 & $v$ & $\downarrow 11$ & $\downarrow 16$ & $\uparrow 2$ & $\uparrow 1$ \\
\hline G-28 & $J-21$ & 50 & 120 & 335 & v & $\downarrow 21$ & $\downarrow 68$ & & $\uparrow 1$ \\
\hline G-29 & $J-16$ & 175 & 120 & 334 & D & $\downarrow 3$ & 0 & $\uparrow 10$ & $\uparrow 3$ \\
\hline G-29 & $\mathrm{J}-22$ & 175 & 120 & 334 & D & $\downarrow 9$ & $\downarrow 16$ & & $\uparrow 2$ \\
\hline G-30 & $\mathrm{J}-17$ & 300 & 120 & 1388 & $v$ & ND & ND & $\uparrow 1129$ * & ND \\
\hline G-30 & $J-23$ & 300 & 120 & 1388 & v & ND & ND & & ND \\
\hline G-31 & $J-18$ & 175 & 120 & 844 & $v$ & $\uparrow 1$ & +13 & $\uparrow 67$ & $\uparrow 3$ \\
\hline G-31 & $J-24$ & 175 & 120 & 844 & $v$ & $\uparrow 9$ & $\uparrow 40$ & & $\uparrow 4$ \\
\hline G-32 & $J-25$ & 175 & 120 & 844 & $v$ & $\downarrow 6$ & $\downarrow 1$ & $\uparrow 36$ & $\uparrow 6$ \\
\hline G-32 & $J-26$ & 175 & 120 & 844 & $v$ & $\downarrow 10$ & $\downarrow 24$ & & $\uparrow 5$ \\
\hline G-10 & $\mathrm{J}-27$ & 300 & 86 & 1032 & $v$ & $\uparrow 28$ & $\downarrow 17$ & $\uparrow 320$ & $\uparrow 22$ \\
\hline G-10 & $\mathrm{J}-28$ & 300 & 86 & 1032 & v & ND & ND & & ND \\
\hline G-33 & $J-29$ & 300 & 120 & 309 & v & $\uparrow 48$ & $\uparrow 75$ & $\uparrow 985$ & $\uparrow 24$ \\
\hline G-33 & I -15 & 300 & 120 & 309 & V & $\downarrow 26$ & $\downarrow 31$ & & $\uparrow 1$ \\
\hline
\end{tabular}


EXPERIMENTAL DATA FOR GALESVILLE SANDSTONE (contd)

\begin{tabular}{|c|c|c|c|c|c|c|c|c|c|}
\hline $\begin{array}{l}\text { Run } \\
\text { No. }\end{array}$ & $\begin{array}{c}\text { Core } \\
\text { No. }\end{array}$ & $\mathrm{T}^{\circ} \mathrm{C}$ & $\underline{P(\text { bars })}$ & $\begin{array}{c}\text { Time } \\
\text { (hours) }\end{array}$ & $\begin{array}{l}\text { Liquid(L) } \\
\operatorname{Vapor}(V) \\
\text { or } \operatorname{Dry}(D) \\
\end{array}$ & $\begin{array}{l}\text { Change } \\
\text { in } \\
\underline{K}_{\text {GAS }}(\not{z})\end{array}$ & $\begin{array}{l}\text { Change } \\
\text { in } \\
\left.\underline{K}_{\text {LIQUID }}(\not)\right)^{(3)}\end{array}$ & $\begin{array}{c}\begin{array}{c}\text { Change } \\
\text { in } \\
\text { Friability }(\%) \\
\end{array} \\
\end{array}$ & $\begin{array}{c}\begin{array}{c}\text { Change } \\
\text { in }\end{array} \\
\text { Porosity }(\%)\end{array}$ \\
\hline G-34 & $I-17$ & 175 & 120 & 309 & v & $\uparrow 4$ & $\uparrow 6$ & $\uparrow 244$ & $\uparrow 1$ \\
\hline G-34 & $I-18$ & 175 & 120 & 309 & v & 0 & $\downarrow 3$ & & 0 \\
\hline G-35 & $I-19$ & 175 & 120 & 309 & v & $\uparrow 5$ & $\downarrow 2$ & $\uparrow 365$ & 0 \\
\hline G-35 & I -20 & 175 & 120 & 309 & v & $\uparrow 1$ & $\downarrow 13$ & & 0 \\
\hline G-36 & $k-1$ & 50 & 120 & 336 & $v$ & $\downarrow 26$ & $\downarrow 26$ & $\uparrow 12$ & 0 \\
\hline G- 36 & $\mathrm{k}-2$ & 50 & 120 & 336 & v & $\downarrow 7$ & +20 & & 0 \\
\hline G-37 & $k-3$ & 175 & 120 & 312 & v & $\downarrow 5$ & $\downarrow 18$ & $\uparrow 98$ & $\uparrow 3$ \\
\hline G-37 & $K-4$ & 175 & 120 & 312 & v & $\uparrow 2$ & $\downarrow 16$ & & $\uparrow 3$ \\
\hline G-38 & $k-5$ & 300 & 120 & 312 & v & $\uparrow 19$ & $\uparrow 21$ & $\uparrow 1093$ & $\uparrow 8$ \\
\hline G-38 & $k-6$ & 300 & 120 & 312 & v & $\uparrow 76$ & $\uparrow 46$ & & $\uparrow 7$ \\
\hline G-39 & $K-7$ & 175 & 120 & 312 & $L$ & $\uparrow 29$ & +39 & $\uparrow 21$ & 0 \\
\hline G-39 & $K-8$ & 175 & 120 & 312 & $L$ & $\uparrow 82$ & $\downarrow 16$ & & $\uparrow 4$ \\
\hline G-40 & $K-9$ & 300 & 120 & 511 & $L$ & $\uparrow 292^{\star}$ & $\uparrow 371 \star$ & $\uparrow 156$ & $\uparrow 25$ \\
\hline G-40 & $K-10$ & 300 & 120 & 511 & $L$ & ND & ND & & ND \\
\hline G-41 & $K-11$ & 175 & 120 & 1004 & v & +18 & $\downarrow 33$ & $\uparrow 2$ & $\uparrow 6$ \\
\hline G-41 & $\mathrm{k}-12$ & 175 & 120 & 1004 & v & $\downarrow 8$ & $\uparrow 5$ & & $\uparrow 4$ \\
\hline G-42 & $K-13$ & 300 & 120 & 1032 & v & $\downarrow 27$ & $\downarrow 47$ & $\uparrow 274$ & 49 \\
\hline G-42 & $K-14$ & 300 & 120 & 1032 & V & $\downarrow 41$ & $\downarrow 51$ & & $\uparrow 23$ \\
\hline
\end{tabular}

ND Not determined because of extensive core degradation

* Anomalous values caused by extensive core degradation

(1) Cycled 5 times between the two temperatures listed

(2) $K_{G A S}=$ nitrogen gas permeability

(3) $K_{\text {LIQUID }}=$ water permeability 

APPENDIX B

ANALYTICAL METHODS AND PROCEDURES 
APPENDIX B

ANALYTICAL METHODS AND PROCEDURES

This section summarizes the analytical methods and procedures used in this study. The physical properties of the samples measured were permeability, apparent porosity, and friability. The extraction procedure of fluid and gas samples, as well as the determination of the chemistry of these samples, is also discussed.

\section{PERMEABILITY AND POROSITY MEASUREMENTS}

Prior and subsequent to each experiment, gas and liquid permeabilities were measured using factory-calibrated Ruska gas and liquid permeameters. Gas permeabilities were measured using nitrogen on desaturated cores that were heated to $105^{\circ} \mathrm{C}$ in an oven for a minimum of 24 hours before the measurement. Liquid permeabilities were obtained from cores that had been evacuated and saturated with deaired, distilled water.

Pre- and post-test apparent porosities $(\phi)$ of sandstone cores were measured using a saturation and caliper technique (Franklin, 1972) and the equation:

$$
\phi(\%)=P_{v} / B_{v} \times 100
$$

where $P_{v}$ and $B_{v}$ are the pore and bulk core volumes, respectively. The bulk volume is calculated from the dimensions of the cylindrical core. The pore volume is determined from the difference in weight of the core after heating to $105^{\circ} \mathrm{C}$ for 24 hours, relative to the core weight after vacuum saturation with distilled water. Figures B.1 and B.2 illustrate the pre-test apparent porosity and permeability of the Galesville sandstone samples used in this experimental study.

\section{FRIABILITY MEASUREMENT}

In an effort to measure differences in friability of reacted and unreacted samples, a quantity related to the modulus of rupture was measured on small 


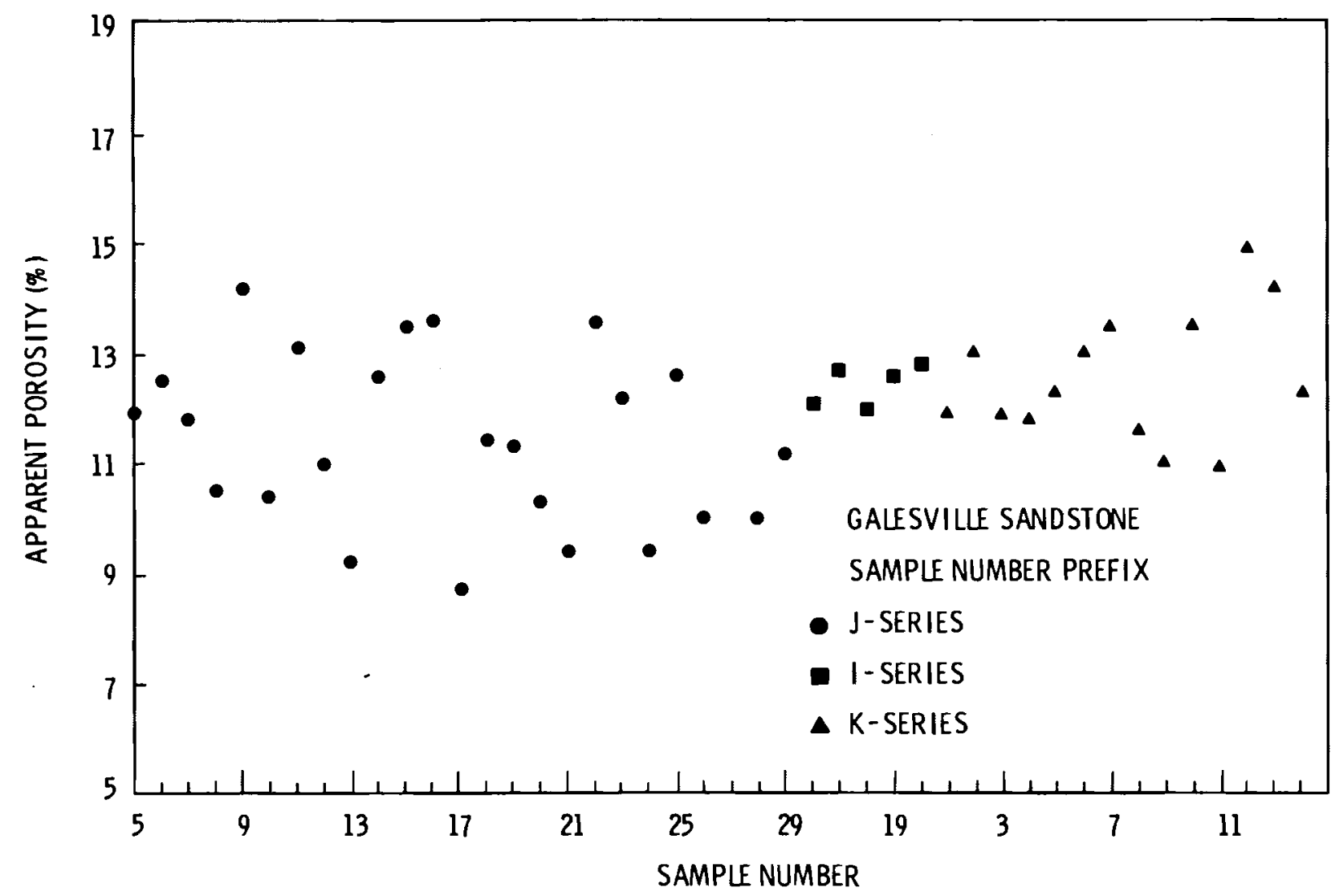

FIGURE B.1. Pre-Test Apparent Porosity of the Galesville Sandstone

discs of sandstone. A modified version of a modulus of rupture apparatus similar to one used by the U.S. Salinity Laboratory (Reeve 1965) was fabricated for this test.

For these measurements, thin sandstone discs $1.82 \mathrm{~cm}$ in diameter by approximately $0.40 \mathrm{~cm}$ thick were prepared from the Galesville sandstone. In each experiment, a sandstone disc was placed above the core in the autoclave pressure vessel as illustrated in Figure $7 \mathrm{a}$ (core $\mathrm{J}-13$ ). To determine the friability of a reacted or unreacted disc, a force normal to the disc diameter was applied at a constant rate until the disc ruptured, thereby breaking grainto-grain contact with in the sample.

The force required to rupture the sample is a function of sample thickness $(t)$, radius $(r)$, and also the cementation of the grains in the sandstone. 


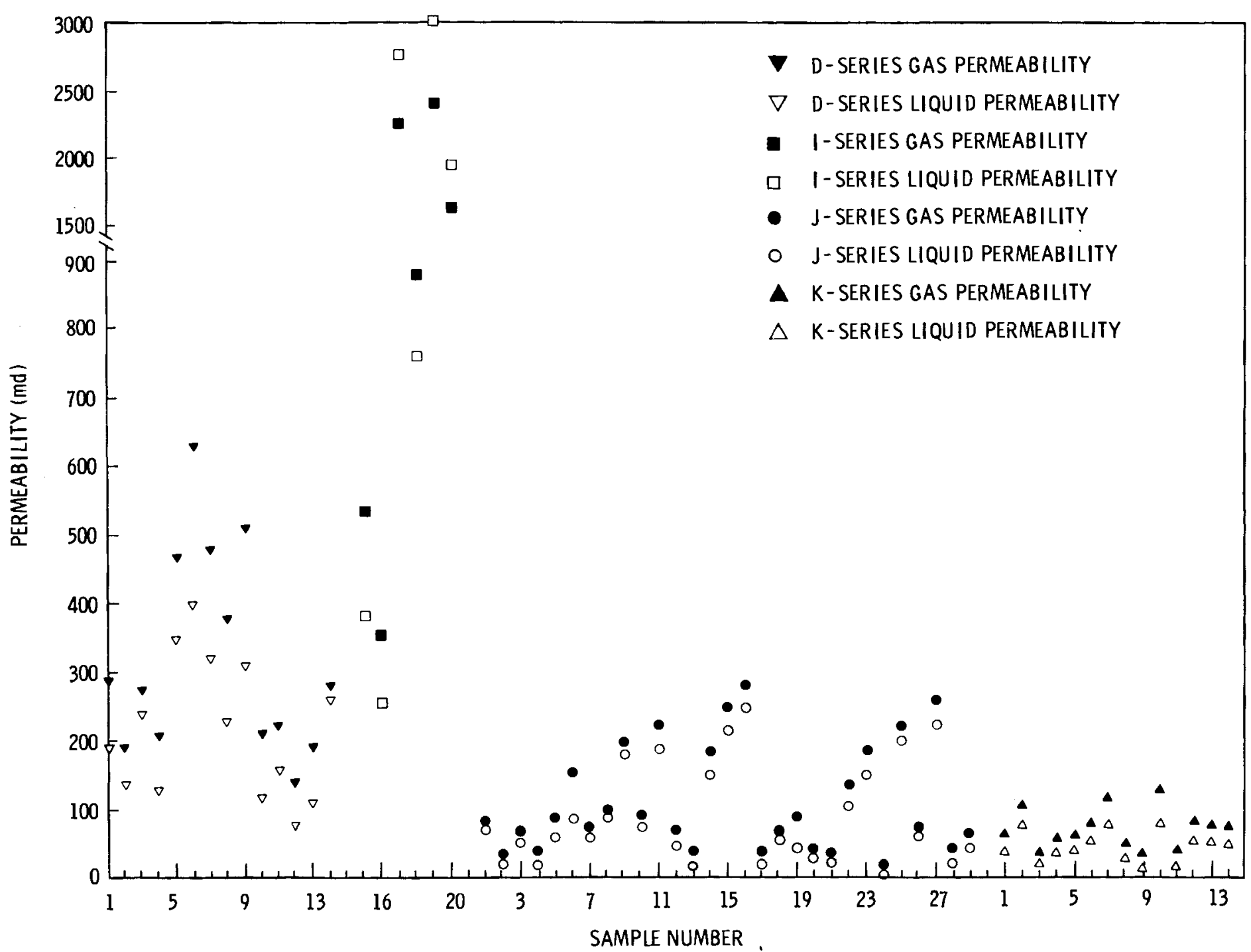

FIGURE B.2. Pre-Test Gas and Liquid Permeabilities of the Galesville Sandstone 
A simple equation for the friability index (FI) is proposed as the bulk volume $\left(V_{b}\right)$ of the disc divided by the weight $(w)$ required to rupture the disc or:

$$
F I \equiv \frac{V_{b}}{w}=\frac{\pi r^{2} t}{w}
$$

For two samples of approximately the same bulk volume, the sample that is more friable will require a smaller weight to cause rupturing and, therefore, will also have a larger value for FI. Although measurement of this empirical index may not rigorously represent a value for friability, it may be used for qualitative comparisons. Comparisons of this type may be useful in evaluating integrity changes that occur when a reservoir rock is subjected to simulated CAES conditions.

\section{MISCELLANEOUS ANALYTICAL TECHNIQUES}

Several comparative techniques were utilized to illustrate the physical and chemical changes that occurred by reacting the sandstone with elevated temperature and pressure air and/or fluids. Photographs of entire samples were obtained for several cores reacted under various temperature, pressure and fluid conditions (Figures $6 a, b$, and 7b) in order to illustrate the physical degradation of the cores. To determine what, if any, mineralogical changes occurred, thin sections of several reacted cores were optically examined using a petrographic microscope. X-ray diffraciograms were obtained for powdered samples. Figures $2 a$ and b illustrate an area of unreacted Galesville sample in plane polarized light and with crossed nicols, respectively. Figures 14a and $b$ illustrate similar samples that have been reacted at $300^{\circ} \mathrm{C}$ in an airwater vapor environment. Bulk chemical analyses of sandstone samples using $X$-ray fluorescence techniques were also obtained and are listed in Table 7.

\section{FLUID AND GAS SAMPLING}

The three types of fluid samples collected during the autoclave experiments were: 1) a liquid sample used for determining elemental concentrations (general analysis), 2) a liquid sample for dissolved $\mathrm{CO}_{2}$ determination, and 3) a gas sample. The sampling apparatus for liquids and gas are illustrated in Figures B.3a and b. 

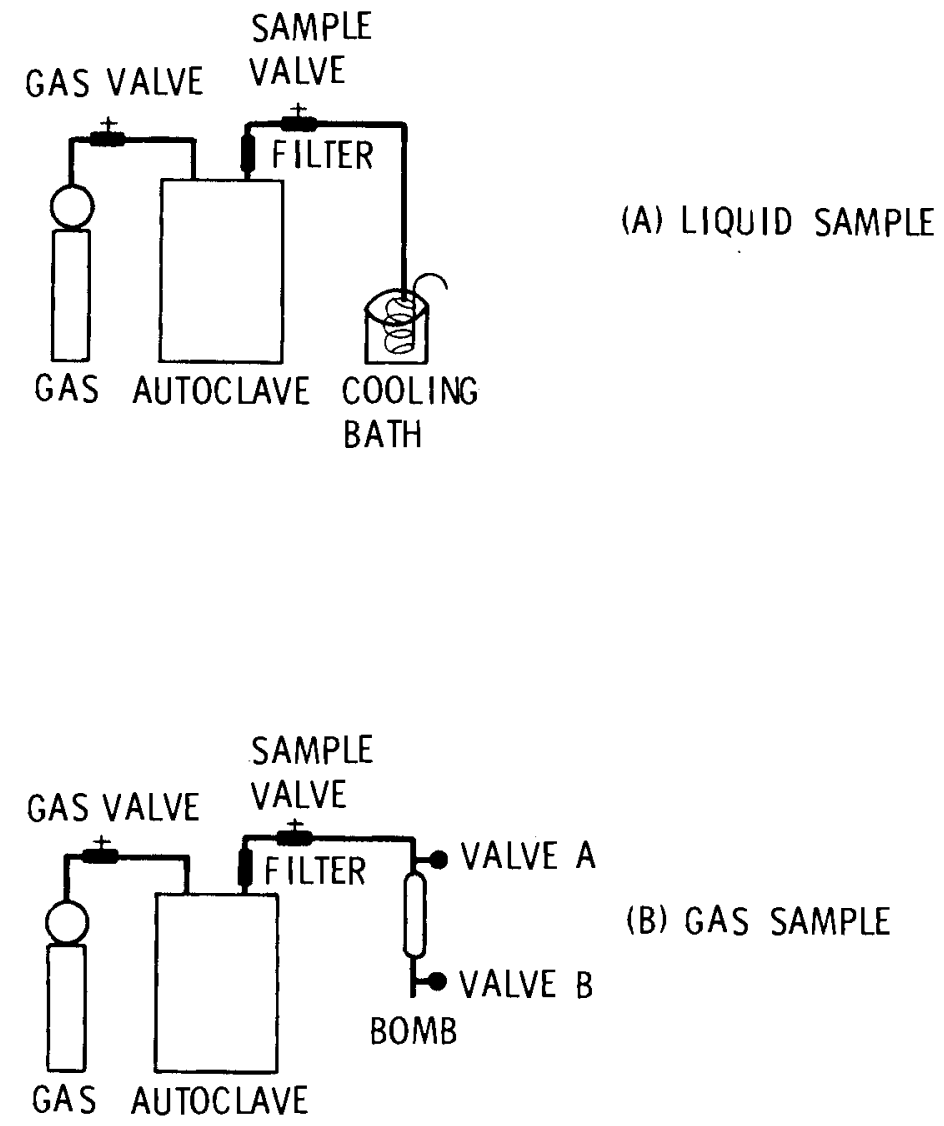

\section{FIGURE B.3. Sampling Apparatus for Extracting Liquid and Gas Samples}

Liquids for general analysis were sampled at run temperature and pressure with an apparatus that includes a micropore filter and a cooling bath (Figure B.3a). Prior to collecting a liquid sample, the sampling valve was opened in order to drain a volume of fluid approximately equal to the volume contained in the sampling system. This procedure removed any residual fluid remaining in the cooling bath from the last sampling. Two fluid samples, each of approximately $10 \mathrm{ml}$, were then collected in capped plastic bottles by slowly opening the sample valve and allowing the fluid to condense in the cooling bath. After sampling, the system was repressurized with compressed gas to the initial pressure selected for the test. One sample was acidified by adding 5 drops of concentrated HCl. The pH of the other sample was measured and recorded and both samples were refrigerated at approximately $2^{\circ} \mathrm{C}$. The she If life for an acidified sample is approximately 1 month. 
The same sampling apparatus used for collecting the general liquid sample (Figure B.3a) was also used to extract a liquid sample needed for dissolved $\mathrm{CO}_{2}$ determination. Before sampling a $10 \mathrm{ml}$ graduated cylinder is filled with $2 \mathrm{ml}$ of $0.1 \mathrm{~N} \mathrm{NaOH}$. The fluid sample, about $10 \mathrm{ml}$, is collected in the graduated cylinder below the fluid level of the $\mathrm{NaOH}$ to assure that no dissolved $\mathrm{CO}_{2}$ escapes. The cylinder is then capped with a rubber stopper (size 0 ) and the total volume of fluid in the cylinder is recorded. The shelf life for these samples is generally several days.

The sampling apparatus for gases is illustrated in Figure B.3b. After sufficient fluid has been drained from the sampling system, a clean and evacuated sample bomb is attached in place of the cooling bath. The sample valve and valve $A$ (Figure B. $3 \mathrm{~b}$ ) are opened and the flow of gas is monitored by noting the pressure drop on the gauge. When the bomb is full, valve $A$ and the sampling valve are closed and the autoclave is repressurized. The gas samples were analyzed with in 5 days.

PROCEDURE FOR LIQUID AND GAS ANALYSIS

The following analytical procedures were employed for the analys is of the liquid and gas samples.

$\mathrm{pH}$ Determination

The $\mathrm{pH}$ of the solution was determined by measuring the potential of the solution between glass and reference electrodes. A dip-type combination Orion electrode and meter equipped with an automatic thermistor temperature compensator was used. The general procedure involved: 1) recording a reading that had been stable for $1 \mathrm{~min}$, or 2 ) the average reading if minor oscillations persisted.

\section{Carbon Dioxide Determination}

Total dissolved $\mathrm{CO}_{2}$ was determined by the American Public Health Association (APHA) standard method 407B. 


\section{Element Concentrations}

The elements Al, B, Ba, Ca, Fe, K, Li, Mg, Na, P, Sr, Ag, As, Cd, Co, Cr, $\mathrm{Cu}, \mathrm{Mn}, \mathrm{Ni}, \mathrm{Pb}, \mathrm{Sb}, \mathrm{Si}, \mathrm{Sn}, \mathrm{Ti}, \mathrm{U}$ and $\mathrm{Zn}$ were analyzed using a Jarrell-Ash Plasma Emission Spectrometer. This instrument is capable of simultaneously determining the concentrations of 31 elements using sample volumes of 5-10 ml per analysis. A background correction system on the spectrometer allows for correction of interelement interferences.

Anion Concentrations

Compressed gases used in the experiments were analyzed using a HewlettPackard Gas Chromatograph. The thermal conductivity detector allows for the determination of hydrogen, carbon dioxide, oxygen, nitrogen and methane. The detection 1 imit is $1000 \mathrm{ppm}$ except for hydrogen which is $10,000 \mathrm{ppm}$ with a precision of $\pm 1 \%$. 
. 


\section{DISTRIBUTION}

No. of

Copies

OFFSITE

A. A. Churm

DOE Chicago Patent Group

Chicago Operations office

9800 South Cass Avenue

Argonne, IL 60439

27 DOE Technical Information Center

B. J. Mueller

Department of Energy

Chicago Operations Office

9800 S. Cass Avenue

Argonne, IL 60439

Dan $\mathrm{Hall}$

P.0. 635

Fairbault, MN 55021

Royal B. Newman

Soyland Power Cooperative, Inc.

P.0. Box A1606

Decatur, IL 62525

G. D. Pezdirtz, Director

Office of Advanced Conservation Technologies

U.S. Department of Energy

600 E. Street, Room 416

Washington, DC 20585

5 Gabor D. Karadi

Department of Energy

Division of Thermal and

Mechanical Energy Storage

600 E. Street, Room 416

Washington, DC 20585
No. of

Copies

D. Willett

Acres American, Inc.

Liberty Bank Building

Main at Court

Buffalo, NY 14202

5 Saul Strauch

Department of Energy

Division of Thermal and

Mechanical Energy Storage

600 E. Street, Room 416

Washington, DC 20585

J. H. Swisher

Division of Thermal and Mechanical Energy Storage

U.S. Department of Energy

600 E. Street, Room 416

Washington, DC 20585

D. W. Boehm

Division of Environmental

Safety and Engineering

U.S. Department of Energy

MS-E201, Germantown

Washington, DC 20545

DOE Library

U.S. Department of Energy

Mail Station G-043

Washington, DC 20585

R. F. Kimberlin

DOE Library

U.S. Department of Energy

Room 1223

Washington, DC 20585 
No. of

Copies

R. B. Schainker

Electric Power Research Institute

3412 Hillview Avenue

P.0. Box 10412

Palo Alto, CA 94303

L. A. Wilson

Middle South Services

P.0. Box 61000

New Or leans, LA 70161

Division of Advanced Energy Research and Technology

Nationa 1 Science Foundation

Room 1140

1800 G Street, NW

Washington, DC 20550

C. G. Nelson

Manager, Storage Operations

Northern Illino is Gas

Company

P.0. Box 190

Aurora, IL 60507

P. E. Schaub

Potomac Electric Power Company

1900 Pennsylvania Avenue

Washington, DC 20006

T. McCafferty

Public Service Company of Ind iana

1000 E. Main Street

Plainfield, IN 46168

Jim Blacic

G-6-LASL-Stop 978

P.0. Box 1663

Los Alamos, NM 87545

C. Cooley

Terra Tek Inc.

University Research Park

400 Wakara Way

Salt Lake City, UT 84108
No. of

Copies

2 Technical Library

Department 3141

Sandia Laboratory

Albuquerque, NM 87115

S. Serata

Serata Geomechanics, Inc.

1229 Eighth Street

Berkeley, CA 94710

Energy Research Section

Tennessee Valley Authority

1360 Commerce Union Bank Bldg.

Chattanooga, TN 37401

Gerald Phillips

Tennessee Valley Authority

1150 Chestnut, Tower 2

Chattanooga, TN 37401

E. Berman

Technical Library

TRW Energy Systems Group

7600 Colshire Drive

McLean, VA 22101

A. J. Giramonti

United Technologies Research

Center

Silver Lane

East Hartford, CT 06108

H. J. Pincus

University of Wisconsin

Department of Geological Sciences

Sabin Hall and Greene Museum

P.0. Box 413

Milwaukee, WI 53201

D. Ayers

Manager, Fluid Systems Laboratory

Westinghouse Electric

Corporation

1291 Cumber land Avenue

West Lafayett, IL 47906 
No. of

Copies

American Public Power Association

2600 Virginia Avenue, NW

Washington, DC 20037

2 J. M. Clinch

Argonne National Laboratory

9700 South Cass Avenue

Argonne, IL 60439

Manager, Research and Development

Bonneville Power Administration

P.0. Box 3621

Portland, OR 97208

Research Library, Reference Section

Information Division

Brookhaven National

Laboratory

Upton, NY 11973

Stan ley Stys

Vice President, American

Brown Boveri Corporation

New Brunswick, NJ 08902

Director of Research

Cincinnati Gas and

Electric Company

139 East Fourth Street

Cincinnati, $\mathrm{OH} 45202$

D. E. DeViney

Commonwea 1th Edison Company

1319 South First Avenue

Maywood, IL 60153

R. A. Bell

Consolidated Edison Company

4 Irving Place

New York, NY 10003
No. of

Copies

T. Schneider

Electric Power Research

Inst itute

Box 10412

Palo Alto, CA 94303

D. Anderson

Fenix and Scisson, Inc.

P.0. Box 15609

Tulsa, OK 74115

Director of Research

GPU Service Corporation

260 Cherry Hill Road

Parsippany, NJ 07054

A. H. Barber

Director of Marketing

Harza Engineering Company

150 S. Wacker Drive

Chicago, IL 60606

Library

Lawrence Berkeley Laboratory

University of California

Bldg. 50, Room 134

Berkeley, CA 94720

3 Technical Information Department, L-3

Lawrence Livermore Laboratory University of California

P.0. Box 808

Livermore, CA 94550

Director of Research

Lou isiana Power and Light

142 Delaronde Street

New Or leans, LA 70174

A. Ferreira

Electric Power Research Institute

NEPLAN

174 Brush Hill Avenue West Springfield, MA 01089 
No. of

Copies

W. Stevens (50/20/B37)

Bechtel National Inc.

Res and Eng.

P.0. Box 3965

San Francisco, CA 94119

Paul Gnirk

$\mathrm{Re} / \mathrm{Spec}$ Inc.

P.0. Box 725

Rapid City, SD 57701

Dona ld L. Katz

Department of Chemical

Engineering

The University of Michigan

2042 E. Engr. B 1dg.

Ann Arbor, MI 48109

R. L. Thoms

Louisiana State University

Institute for Environmental Studies

Room 42, Atkinson $\mathrm{Ha} 11$

Baton Rouge, LA 70803

A. F. Fossum

$\mathrm{Re} / \mathrm{Spec}$ Inc.

P.0. Box 725

Rapid City, SD 57701

0. C. Farquhar

Univ. of Massachusetts

Dept. of Geology and Geography

Morri11 Science Center

Amherst, MA 01003

T. L. Brekke

University of California

Department of Civil Engineering

1847 Yosemite Road

Berkeley, CA 94707

H. Lorenzen

PB-KBB Inc.

Subsurface Systems and Techno logy

800 Commerce Road West

Harahan, LA 70123
No. of

Copies

A. H. Warnke

Vice Present Power Supply

Central Illinois Public

Service Co.

607 East Adams Street

Springfield, IL 62701

G. E. Huck

Manager of Planning

Illino is Power Company

500 South 27th St.

Decatur, IL 62525

W. C. Walke

Project Manager

Sargent and Lundy Engineers

55 East Monroe Street

Chicago, IL 60603

T. J. Maiman

Sta. Mech. Engr. Dept. Manager

Commonwea 7 th Edison Co.

36 FN West

P.0. Box 767

Chicago, IL 60690

E. M. Mabuce

Manager-Applied Research

Corporate Planning Dept.

Union Electric Co.

P.0. Box 149

St. Louis, MO 63166

W. F. Kobett

CAES Project Manager

West inghouse Electric Corp.

Combustion Turbine Sys. Div.

Long Range Development-Lab 100

P.0. Box 251

Concordville, PA 19331

J. C. Smith

Division of Electrical Energy Systems

Department of Energy

12 and Pennsylvania, Room 6144

Washington, DC 20585 
No. of

Copies

J. Gah imer

Department of Energy

Division of Thermal and Mechanical Energy Storage

600 E Street, Room 416

Washington, DC 20585

C. Holt

Battelle Columbus Laboratories 505 King Avenue

Columbus, $\mathrm{OH} 43201$

T. Bar low

Lawrence Livermore Laboratory

P.0. Box 808

Livermore, CA 94550

H. M. Dodd

Organization 5743

Sandia Laboratories

Albuquerque, NM 87115

R. 0 . Woods

Organization 4715

Sandia Laboratories

Albuquerque, NM 87115

J. L. Nash-Webber

MIT

Energy Lab

Cambridge, MA 02139

R. D. Lessard

United Technologies Research

Center

Silver Lane

East Hartford, CT 06108

M. J. Hobson

Acres American, Inc.

The Clark Bldg.

Suite 329

Columbia, MD 21044
No. of

Copies

FOREIGN

I. Glendenning

Head of Long-Term Studies

Marchwood Engineering Labs

Southampton, England

ONSITE

2 DOE Richland Operations Office
D. K. Jones
H. E. Ransom

64 Pacific Northwest Laboratory

R. D. Allen

M. C. C. Bampton

S. M. Brown

T. J. Doherty

M. K. Drost

R. L. Erikson (15)

J. A. Fort

J. R. Friley

P. J. Gutknecht

A. J. Haverfield

J. J. Jacobson

L. D. Kannberg

W. S. Kelly

W. V. Loscutoff (15)

R. P. Marshall

R. A. McCann

M. A. Mckinnon

L. T. Pedersen

R. W. Reilly

R. P. Smith

J. A. Stottlemyre

A. M. Sutey

D. S. Trent

L. E. Wiles

Water and Land Resources Library (5)

Technical Information (5)

Publishing Coordination (SH) 
